Kontribusi R.A.A. Wiranatakoesoema...... | Asep Achmad H, dkk

\title{
KONTRIBUSI R.A.A. WIRANATAKOESOEMA V DALAM MENERJEMAHKAN SEJARAH NABI MUHAMMAD saw. DI TATAR SUNDA TAHUN 1941 \\ (Karya: Riwajat Kangdjeng Nabi Moehammad saw.)
}

\author{
Asep Achmad Hidayat, Suparman, Ratu Asih Anggie Satiti \\ Fakultas Adab dan Humaniora Universitas Islam Negeri \\ Sunan Gunung Djati Bandung \\ Email: asepachmadhidayat@ uinsgd.ac.id
}

\begin{abstract}
Translation has an important role in the dissemination of knowledge, religious teachings, and culture existing throughout the world. The ex-Regent of Bandung R.A.A. Wiranatakoesoema $V$ gave contribution to Sundanese language with his translation work in the field of religion. He translated the works of E. Dinet and Sliman bin Ibrahim by using two writing models, namely combining modern European writing in the form of prose, in line with traditional Sundanese writing traditions, called dangding. His work was published in 1941 entitled Riwajat Kangdjeng Nabi Moehammad, peace be upon him. This book became an early historical literature of prophets printed using Latin and Arabic characters, and it contributed to the translation style in the Sundanese Land.
\end{abstract}

Keywords: R.A.A. Wiranatakoesoema V, Translation, Dangding. 


\section{Pendahuluan}

Penerjemahan merupakan salah satu cara utama dalam menyebarkan pengetahuan dari satu bahasa ke dalam bahasa lain, yang berasal dari suatu daerah ke daerah lain. Hingga sebuah pengetahuan mampu tersebar luas ke seluruh penjuru dunia dan diketahui oleh beragam suku bangsa dengan berbagai bahasa. Dengan kata lain, peran dan posisi penerjemah sangatlah penting sebagai penyambung lidah, penerus maksud, pengantar pesan, serta penghubung antara satu budaya dengan budaya lainnya. Sebuah tulisan dapat melintasi ruang dan waktu karena kerja sang penerjemah. ${ }^{1}$ Kajian ini terkait dengan sejarah penerjemahan di Indonesia dalam konteks kolonial, terutama dalam penerjemahan yang terjadi di Tatar Sunda, khususnya masyarakat Pasundan.

Penerjemahan di Tanah Sunda sudah terjadi sebelum percetakan masuk ke Hindia Belanda. Secara umum, penerjemahan ke dalam bahasa Sunda cenderung menggunakan bentuk wawacan (dangding berbentuk cerita). Naskah-naskah berbentuk macapat atau babad dalam bahasa Jawa dan syair, atau hikayat dalam bahasa Melayu digubah menjadi wawacan dalam bahasa Sunda. Baik macapat maupun wawacan masing-masing memiliki ketentuan yang ketat dalam penulisannya, ketentuan ini mengatur jumlah larik dalam setiap bait, jumlah suku kata dalam setiap larik juga vokal suku kata terakhir dari setiap larik. Penulisan syair pun terikat dengan ketentuanketentuan khusus tersendiri. Dapatlah dibayangkan, bahwa penerjemahan yang dilakukan secara harfiah atau ketepatan terjemah pada setiap kalimat tidaklah mungkin. ${ }^{2}$ Sehingga, keahlian menggubah dangding atau wawacan ini menjadi keunggulan di kalangan orang Sunda. Sehingga, R.A.A. Wiranatakoesoema $\mathrm{V}$ pun ikut mempertahankan tradisi menulis dangding meski gaya penulisan Barat mulai menjamah dan diserap oleh masyarakat Sunda.

Jika ditelusuri jejaknya, wawacan merupakan pengaruh tradisi sastra Jawa yang dibawa oleh Kesultanan Mataram ketika menduduki Tanah Sunda. Pada masa politik dan kebudayaan Sunda berpaling ke Jawa, pengetahuan dan keterampilan di bidang bahasa dan sastra Jawa kiranya dianggap bagian dari ciri-ciri keterpelajaran orang Sunda. ${ }^{3}$ Pandangan ini terus terbawa hingga masa pendudukan Belanda. Tidak heran, jika banyak karya-karya dalam bentuk

\footnotetext{
${ }^{1}$ Lina Meilinawati Rahayu, Penerjemahan Karya Sastra Ke Dalam Bahasa Sunda Sebagai Strategi Pemberdayaan Bahasa Lokal, (Bandung: Jurnal Tutur Universitas Padjadjaran Vol. 1 No. 1, Februari 2015), hlm. 79.

${ }^{2}$ Ajip Rosidi, Masa Depan Budaya Daerah: Kasus Bahasa dan Sejarah Sunda, (Jakarta: PT Dunia Pustaka Jaya, 2004), hlm. 76.

${ }^{3}$ Hawe Setiawan, sebuah esai berjudul: Dangding Mistis Haji Hasan Mustapa, Sumber: salihara.org Kalam 28/2016, Diakses pada 31 Juli 2018.
} 
syair atau hikayat dari Melayu, macapat maupun serat dari Jawa kemudian disadur atau diterjemahkan ke bahasa Sunda dalam bentuk wawacan.

\section{Biografi Singkat R.A.A. Wiranatakoesoema V}

Pemilik nama lengkap Raden Adipati Aria Wiranatakoesoema V adalah salah satu tokoh yang namanya tercatat dalam sebuah buku berjudul Orang Indonesia jang Terkemoeka di Djawa (1944). Buku yang terbit pada masa pendudukan Jepang ini memaparkan ikhtisar orang-orang Indonesia yang terkemuka, yang memiliki kedudukan, kepandaian atau pekerjaan yang berpengaruh di kalangan masyarakat Jawa. ${ }^{4}$ Sebagai orang yang terkemuka, R.A.A. Wiranata-koesoema V memiliki kedudukan yang tinggi. Darah yang mengalir dalam tubuhnya adalah faktor utama yang memengaruhi status sosialnya. Ia lahir dari keluarga keturunan menak tertinggi sebagai anak sekaligus cucu dari bupati Bandung terdahulu.

R.A.A. Wiranatakoesoema $\mathrm{V}$ merupakan menak pangreh praja yang dididik dan ditarik menjadi birokrasi pemerintahan kolonial Belanda. Ayahnya Raden Tumenggung Kusumadilaga (1874-1893) adalah Bupati Bandung ke- $9^{5}$ yang masyhur dengan gelar Dalem Marhum dan ibunya Raden Ayu Sukarsih. Kakeknya Raden Adipati Wiranatakoesoema III (1829-1846) Bupati Bandung ke-7 dengan gelar Dalem Karanganyar dan Uaknya Raden Adipati Wiranatakoesoema IV (1846-1874), Bupati Bandung ke-8 yang bergelar Dalem Bintang. Hingga akhirnya R.A.A. Wiranatakoesoema V pun mengikuti para leluhurnya menjadi Bupati Bandung dalam dua kali periode dengan gelar Dalem Haji. ${ }^{6}$ Beliau lahir di Bandung pada tanggal 8 Agustus 1888. ${ }^{7}$ Adapun keterangan lain yang tertulis pada nisannya, bahwa ia lahir pada tanggal 23 November 1888 dan wafat pada 22 Januari $1965 .{ }^{8}$ R.A.A. Wiranatakoesoema $\mathrm{V}$ juga memiliki nama kecil yang akrab disapa Moeharam. Ia merupakan putra tunggal dan telah menjadi yatim di usia lima tahun. Moeharam pun hidup dalam asuhan ibu dan neneknya hingga ia berusia sembilan tahun. Beliau dibesarkan dalam lingkungan bumiputra dan dididik sebagaimana anak-anak bumiputra tumbuh. Sejak kecil ia telah mahir menabuh gamelan, memetik kecapi, dan mengenal ragam lagu Sunda serta

\footnotetext{
${ }^{4}$ Gunseikanbu, Orang Indonesia Jang Terkemoeka Di Djawa, cet. I, (Jakarta: Gunseikanbu, 2604), hlm. 5.

${ }^{5}$ Terhitung dari periode Raden Tumenggung Wirawinangun (1641-1681). Lihat, Nina Herlina Lubis, Kehidupan Kaum Menak Priangan 1800-1942, (Bandung: Pusat Informasi Kebudayaan Sunda, 1998), hlm. 315.

${ }^{6}$ Prasasti Masdjid Kaoem Boeahbatoe.

${ }^{7}$ Arsip Orang Terkemuka di Jawa No. 2922, Lembar Pendaftaran Orang Indonesia Jang Terkemoeka Jang Ada Di Djawa, (Bandoeng: Gunseikanbu Tjabang I, 2603).

${ }^{8}$ Makam Para Boepati Bandoeng: Makam R.H.A.A. Wiranatakusumah V Bupati Bandung ke-XI.
} 
lagu-lagu keagamaan. Rasa gembiranya pun tidak terbendung kala mendengarkan cerita-cerita wayang. ${ }^{9}$ Tampaklah bahwa Moeharam begitu mencintai dirinya yang lahir sebagai bumiputra sejati.

Sejak ayahnya wafat, pada tahun 1893 kursi Bupati Bandung diisi oleh R.A.A. Martanegara, ${ }^{10}$ keponakan Pangeran Sugih, Bupati Sumedang, untuk menggantikan posisi Moeharam yang masih belia. Pada saat itu R.A.A. Martanegara berusia 48 tahun dan berperan sebagai wali Moeharam. Ia merupakan seorang menak Sumedang yang produktif menulis, baik ketika di waktu luang saat menjabat sebagai bupati maupun setelah beliau pensiun. Karya tulisnya tergolong karya sastra serta karya sastra sejarah. Sehingga dianggap memberikan sumbangan yang cukup besar terhadap perkembangan kesusastraan Sunda pada tahun 1920-an. ${ }^{11}$ Tidak dapat dipungkiri, kecintaannya terhadap sastra tertanam pada diri anak asuhnya, R.A.A. Wiranatakoesoema V kecil.

Selain R.A.A. Martanegara, Moeharam pun dididik oleh dua sanak saudara lain yang sekaligus menjadi walinya: Raden Ardinegara seorang Jaksa Bandung dan Raden Suryadiningrat seorang Camat Cilokotot (Cimahi). ${ }^{12}$ Dengan demikian Moeharam memiliki tiga orang wali sekaligus dan kepada ketiganya dipasrahkan kewajiban untuk mengurus semua warisan almarhum Kusumadilaga. Berkat warisan ayahnya, Moeharam dapat menimba ilmu di sekolah elite ELS (Europeesche Lagere School) ${ }^{13}$ yang menjadi langkah awal pendidikan formalnya di Bandung kemudian lulus pada tahun 1901.14 Menginjak usia sembilan tahun ia dididik oleh beberapa orang Eropa diantaranya: Adams, Dr. Snouck Hurgronje, dan G.A.J. Hazeu. ${ }^{15}$ Lingkungan sekolah dan asuhan orang-orang Eropa ini menjadi sebab terbentuknya kefasihan Moeharam dalam berbahasa asing. Keahlian berbahasanya semakin meningkat ketika pindah dari OSVIA (Opleidingsschool voor Inlandsche

\footnotetext{
${ }^{9}$ R.A.A. Wiranata Koesoema, Perdjalanan Saja ke Mekkah, dalam Henri Chambert-Loir, Naik Haji Di Masa Silam: Kisah-kisah Orang Indonesia Naik Haji 1482-1964, Jilid II, (Jakarta: Kepustakaan Populer Gramedia, 2013), hlm. 639-640.

${ }^{10}$ Mangle, No. 1233, 25-31 Januari 1990, hlm. 40.

${ }^{11}$ Nina Herlina Lubis, Kehidupan Kaum..., hlm. 239.

${ }^{12}$ Henri Chambert-Loir, Naik Haji..., hlm. 552.

${ }^{13}$ Europeesche Lagere School atau Sekolah Dasar Eropa merupakan sekolah yang mencontoh sekolah dasar yang ada di Belanda. Pendidikan yang diberikan meliputi pelajaran menulis, membaca, berhitung, bahasa Belanda, sejarah, dan ilmu bumi. Lihat, Nina Herlina Lubis, dkk, Sejarah Provinsi Jawa Barat, jilid II, (Bandung: Pemerintah Provinsi Jawa Barat, 2011), hlm.8.

${ }^{14}$ Arsip Orang Terkemuka di Jawa No. 2922, Lembar Pendaftaran Orang Indonesia Jang Terkemoeka Jang Ada Di Djawa, (Bandoeng: Gunseikanbu Tjabang I, 2603).

${ }^{15}$ Iip Dzulkifli Yahya, Wiranatakusumah, "Sosok Nu Masagi”, (Bandung: Selisik Pikiran Rakyat, Senin (PON) 1 Maret 2010; 15 Rabiul Awal 1431 H; Mulud 1943), hlm. 28.
} 
Ambtenaren $)^{16}$ ke HBS (Hogere Burger School) atau Gymnasium Willem III di Batavia, sebuah sekolah lanjutan bergengsi yang selain biayanya mahal para calon pelajar harus melalui ujian masuk yang sulit seperti: ujian bahasa Belanda, bahasa Perancis dan ilmu hitung. ${ }^{17}$ Moeharam pun mendapat bimbingan les bahasa Perancis, Jerman dan Inggris secara intensif setiap satu pekan sekali dari Snouck Hurgronje. ${ }^{18}$

Prestasi R.A.A. Wiranatakoesoema V di kancah pemerintahan kolonial menorehkan hasil yang gemilang. Beliau diangkat menjadi Bupati Cianjur ketika usia 24 tahun dan menjadi bupati termuda di Hindia Belanda. Kemudian pada tahun 1920, beliau menduduki jabatan Bupati Bandung dan menghidupkan kepemimpinannya dengan dominasi sastra Sunda. Ia menerbitkan surat kabar Obor sebagai wadah komunikasi antara pegawai pemerintah desa dengan sang Bupati. Melalui media inilah berbagai kebijakan pemerintah dijelaskan dalam bentuk dangding atau pupuh. Begitu pun para aparat kecamatan dan desa, yang menanggapi dan bertanya perihal aturan tersebut menggunakan dangding dan pupuh. ${ }^{19}$ Bagi beliau, menggunakan bahasa ibu dan sastra Sunda adalah bagian penting untuk berkomunikasi dengan masyarakat Sunda agar apa yang disampaikan lebih mudah dipahami dan lebih berkesan di hati.

Selain itu, ia pun menaruh perhatian yang besar terhadap Islam dengan merintis BPK (Badan Perserikatan Keluarga) bertujuan untuk membentuk komunitas-komunitas kecil yang sehat dan damai sesuai dengan prinsipprinsip yang diajarkan Al-Qur'an, kemudian membangun Baitul Mal sebagai solusi menangani krisis perekonomian rakyat, 20 melestarikan kesenian mamaos yang menyenandungkan ayat-ayat Al-Qur'an, ${ }^{21}$ membangun Masjid Kaoem Boeahbatoe serta menulis berbagai karya tentang ke-Islaman seperti: Mi'raj Kangdjeng Nabi Moehammad saw, Mijn Reis naar Mekka (kisah perjalanan hajinya), De Beteekenis Der Mohammedaansche Feestdagen,

\footnotetext{
${ }^{16}$ OSVIA adalah sekolah khusus untuk calon pegawai negeri pribumi (pangreh praja). Pada awalnya nama sekolah ini adalah Hoofdenschool yang artinya Sekolah Menak. Hingga pada Agustus 1900 diubah menjadi OSVIA (Opleidingsschool voor Inlandsche Ambtenaren) dan penerimaan murid tidak lagi diskriminatif hanya untuk anak-anak pegawai dan tokoh terkemuka tetapi terbuka untuk umum. Lihat, Nina Herlina Lubis, dkk, Sejarah Provinsi Jawa Barat, Jilid II, (Bandung: Pemerintah Provinsi Jawa Barat, 2011), hlm. 24.

${ }^{17}$ Nina Herlina Lubis, Kehidupan Kaum..., hlm. 114, 105-106.

${ }^{18}$ Iip Dzulkifli Yahya, R.A.A.H.M. Wiranatakusumah..., hlm. 2; Henri Chambert-Loir, Naik Haji..., hlm. 552.

${ }^{19}$ Iip Dzulkifli Yahya, Sosok Pemimpin yang Dicintai Rakyatnya, (Bandung: Selisik Pikiran Rakyat, Senin (PON) 1 Maret 2010; 15 Rabiul Awal 1431 H; Mulud 1943), hlm. 29; Iip Dzulkifli Yahya, R.A.A.H.M. Wiranatakusumah..., hlm. 13.

${ }^{20}$ Iip Dzulkifli Yahya, R.A.A.H.M. Wiranatakusumah..., hlm. 17-18.

${ }^{21}$ Dian Hendrayana, Wiranatakusumah, Degung, dan Cianjuran, (Bandung: Selisik Pikiran Rakyat, Senin (PON) 1 Maret 2010; 15 Rabiul Awal 1431 H; Mulud 1943), hlm. 30.
} 
dimuat dalam Majalah Penjoeloeh (tentang arti penting hari-hari besar Islam), Choetbah Lebaran 1 Syawal 1355, Moreele en Geetelijke Herbewapening uit Islamietisch Oogpunt (tentang pembaharuan moral dan spiritual dari sudut pandang Islam), Islamiestische Democratie in Theorie en Praktijk (tentang demokrasi Islam dalam teori dan praktik), Het Leven van Muhammad de Profeet van Allah yang diterjemahkan ke dalam bahasa Sunda, Riwajat Kangdjeng Nabi Moehammad saw, Tafsir Surat al-Baqarah (sebuah tafsir satu Surat al-Qur'an yang ditulis dalam bahasa Sunda dan dalam bentuk dangding, karya ini ditulis bersama R.A.A. Soeriamiharja) dst. Sejak kepulangannya dari tanah suci, sang Bupati digelari Dalem Haji dan terlihat lebih Islami. Beliau kerap menggunakan pakaian khas Arab ketika melaksanakan ibadah salat Jum'at maupun salat Id. Latar belakang inilah yang membentuk karakter dan pola pikir R.A.A. Wiranatakoesoema V. Riwayat kehidupan keluarga serta pendidikannya pun banyak memengaruhi karya-karyanya.

\section{Latar Belakang Penerjemahan Buku Riwajat Kangdjeng Nabi Moehammad Saw.}

Sebuah karya tulis tercipta tidak luput dari motif dan tujuan sang penulis. Penulis sangat dipengaruhi oleh situasi zaman, lingkungan kebudayaan, dan tempat dimana karya tersebut dihasilkan. Beberapa karya biasanya muncul sebagai bentuk kegelisahan intelektual dan respon penulis terhadap keadaan atau bahkan tuntutan orang-orang di sekitarnya. Dengan demikian, antara penulis dan lingkungannya terdapat hubungan yang sangat kuat dalam membentuk corak, karakter, maupun model sebuah tulisan. ${ }^{22}$ Buku Riwajat Kangdjeng Nabi Moehammad saw. (1941) karya R.A.A. Wiranatakoesoema $\mathrm{V}$ adalah sebuah karya terjemahan dari buku berbahasa Inggris yang berjudul The Life of Mohammad, The Prophet of Allah (1918) karya Etienne Dinet dan Sliman bin Ibrahim. Bagi R.A.A. Wiranatakoesoema $\mathrm{V}$ buku The Life of Mohammad merupakan karya tulis berharga yang sangat disayangkan bila tidak dipublikasikan kepada khalayak luas. Sehingga, setelah membacanya ia berinisiatif untuk menerjemahkan buku tersebut ke dalam dua bahasa, Belanda dan Sunda.

Nalika sawatara taoen ka toekang, djisim koering nampi boekoe, kenging E. Dinet sarěng Sliman bin Ibrahim, The Life of Mohammad, anoe bahasa Inggris, enggal disalin kana basa Walanda, soepados anoe tariasa basa Walanda, katarik kěrsa maos hidji boekoe, anoe pinoeh koe pěpěnděman, anoe tanpa wangěnan hargana, toer kaloeli-loeli keneh pisan koe noe seueur mah. $^{23}$

22 Ajid Thohir, Sirah Nabawiyah: Nabi Muhammad saw Dalam Kajian Ilmu SosialHumaniora, (Bandung: Penerbit Marja, 2014), hlm. 37.

${ }^{23}$ R.A.A. Wiranata Koesoema, Riwajat Kangdjeng Nabi Moehammad saw., (Bandung: Islam Studieclub, 1941), hlm. vii. 
Artinya:

Beberapa tahun yang lalu, saya (R.A.A. Wiranatakoesoema V) memperoleh buku, karya E. Dinet dan Sliman bin Ibrahim, The Life of Mohammad, yang berbahasa Inggris, segera diterjemahkan ke dalam bahasa Belanda, agar yang mampu berbahasa Belanda, tertarik (mau) membaca sebuah buku, yang penuh dengan khazanah ilmu, yang tidak ternilai harganya, dan yang masih terlupakan oleh banyak orang.

Buku The Life of Mohammad selesai ditulis pada 28 Juli 1916 M/27 Ramadhan $1334 \mathrm{H}$ di Bu-Saada. Karya ini dikeluarkan dalam edisi terbatas sebanyak 125 salinan, yang ditulis pada perkamen kualitas tinggi masa kekaisaran Jepang, serta dilengkapi dengan beberapa gambar. Kemudian diterbitkan sebanyak 875 salinan yang dicetak pada kertas buatan tangan oleh The Paris Book Club tahun 1918. Setiap salinan terdiri dari 10 bab, 177 halaman dengan tambahan ix halaman awal, dihiasi oleh 27 gambar karya E. Dinet beserta 12 halaman ornamental karya Mohammad Racim. Buku ini termasuk karya historiografi Islam modern karena dilengkapi oleh bibliografi, daftar isi, daftar gambar dan daftar terjemahan 25 kaligrafi Arab. Bahkan, E. Dinet dan Sliman bin Ibrahim menyediakan peta Hijaz dan kota Mekah. ${ }^{24}$ Karya ini mula-mula diterjemahkan oleh R.A.A. Wiranatakoesoema V ke dalam bahasa Belanda pada tahun 1940 dengan judul Het Leven van Muhammad, de Profeet van Allah. Buku berbahasa Belanda ini diterbitkan di Bandung oleh Islam Studieclub. Tidak diketahui berapa jumlah salinan yang telah dicetak. Namun, peneliti telah menemukan salinannya di beberapa tempat yang berbeda, sehingga dapat dipastikan bahwa buku tersebut dicetak lebih dari satu salinan. Masing-masing salinan diterjemahkan sesuai karya aslinya, baik jumlah gambar maupun bab.

R.A.A. Wiranatakoesoema $\mathrm{V}$ pada bagian awal buku menambahkan 3 halaman untuk kata pengantar penerjemah, pada bagian akhir buku, ia mengubah peta jazirah Arab dan kota Mekah yang asalnya satu gambar menjadi dua gambar terpisah dan menambahkan pula peta kota Madinah. Tidak hanya itu, ia mempermudah pembaca dengan menyediakan transkripsi bahasa Arab ke latin, tabel geneaologi Nabi Muhammad saw., serta indeks berjumlah 22 halaman. Selain menambahkan beberapa bagian, ia juga mengurangi jumlah ornamental halaman dari 12 menjadi 2. Sehingga total halaman ialah 222 dengan tambahan xii halaman. ${ }^{25}$ Satu tahun kemudian, R.A.A. Wiranatakoesoema V menerbitkan versi bahasa Sunda yang berjudul Riwajat Kangdjěng Nabi Moehammad saw.:

\footnotetext{
${ }^{24}$ E. Dinet dan Sliman Ben Ibrahim, The Life of Mohammad - The Prophet of Allah, (Paris: The Paris Book Club, 1918), hlm i-177.

${ }^{25}$ R.A.A. Wiranata Koesoema, Het Leven van Muhammad - De Profeet van Allah, (Bandung: Islam Studieclub MCMXL, 1940), hlm. i-222.
} 
Di tanah Pasoendan parantos aja milioenan anoe tariasa matja aksara Walanda, koe djisim koering ieu riwajat Nabi saw., disalin deui tina basa Walanda kana basa Soenda koe aksara Walanda. ${ }^{26}$

Artinya:

Di tanah Pasundan sudah ada jutaan orang yang mampu membaca huruf Belanda (huruf Latin), oleh saya riwayat Nabi saw. ini, ditulis kembali dari bahasa Belanda ke dalam bahasa Sunda dengan menggunakan huruf Belanda (huruf Latin).

Dari kutipan di atas, R.A.A. Wiranatakoesoema $\mathrm{V}$ menaruh harapan besar agar karyanya mudah diterima oleh seluruh masyarakat yang mampu membaca huruf Latin, yang umumnya menggunakan bahasa Belanda dan Sunda. Sebagai seorang Bupati yang hidup dalam lingkungan pemerintah kolonial, pun lingkungan masyarakat Sunda, ia menyadari bahwa bahasa merupakan akses penting untuk berkomunikasi. Latar belakang pendidikannya menunjang R.A.A. Wiranatakoesoema $\mathrm{V}$ untuk menguasai beberapa bahasa asing seperti bahasa Belanda, Inggris, Jerman, dan Perancis. Sedangkan latar belakang keluarga membentuk dirinya menjadi seorang bumiputera yang fasih berbahasa Sunda. Dengan keahliannya itu, ia berupaya untuk berbagi hasil bacaan yang telah ia peroleh dengan cara menerjemahkannya sesuai bahasa yang digunakan oleh pembaca. Sehingga mempermudah pembaca untuk memahami maksud dan pesan yang hendak disampaikan.

Adapun tujuan utama R.A.A. Wiranatakoesoema V menerjemahkan buku The Life of Moha-mmad ialah kandungan isi dari karya tersebut yang membahas tentang sejarah kehidupan Nabi Muhammad saw. Ajaran Islam meletakkan kedudukan Nabi Muhammad saw. sebagai tokoh sentral manusia pertama yang wajib diimani dan ditaati. Hal ini menjadi syarat utama diakuinya keimanan seseorang sebagai seorang muslim.

Dengan melafalkan dua kalimat syahadat, seseorang telah melegitimasi dirinya sebagai pemeluk Islam sekaligus telah membuat perjanjian dengan Allah Swt. Maka ketika seorang muslim ingkar serta memalingkan keimanannya terhadap Allah dan Rasul-Nya maka batal pula keIslamannya. Sehingga ia murtad dan diwajibkan untuknya mengucapkan lagi dua kalimat syahadat, untuk mengembalikan ke-Islamannya. Dengan demikian, kalimat syahadat merupakan rukun Islam pertama yang menjadi nilai tauhid terdasar dan terpenting dalam ajaran Islam.

Roekoen kahidji, anoe dipěrédih koe Islam, ngoetjapkeun ,Kalimah kalih", noe oenggělna : Asjahadoe an la Ilahaill-Allah, wa asjahadoe anna Moehammadan 'l Rasoeloellah”. Těgěsna : „Kaoela njaksian, hěnteu aja noe Hak disěmbah, anging Allah, sarta kaoela nyaksian, Nabi Moehammad saw. Oetoesan Andjeuna”.

${ }^{26}$ R.A.A. Wiranata Koesoema, Riwajat Kangdjeng..., hlm. vii. 
Kontribusi R.A.A. Wiranatakoesoema...... | Asep Achmad H, dkk

Toedoeh Iman dina kalimah kadoea, djadi kawadjiban sadajana Moeslim, mapaj raratan, njoektjroek galoerna Rasoeloellah saw., sangkan woewoeh koekoeh, noe disaksian koe lisanna tea.

Dina saniskantěn tingkah polah andjeunna, maparin toeladan kasampoernä̈nana manoesa, anoe njoemponan taklif, papantjen Wet Allah taäla. ${ }^{27}$

Artinya:

Rukun pertama, yang diperintahkan oleh Islam, mengucapkan „Kalimat syahadat" yang perkataannya: Asyhadu an la Ilahailla-Allah, wa asyhadu anna Muhammadan Rasulullah”. Definisinya: „Saya bersaksi, tidak ada Tuhan yang berhak disembah, kecuali Allah, dan saya bersaksi, Nabi Muhammad saw. utusan-Nya".

Petunjuk Iman pada kalimat kedua, menjadi kewajiban seluruh Muslim, menelusuri keterangan-keterangan (yang ditinggalkan Rosulullah saw.), menelaah jalan kehidupan Rasulullah saw., agar semakin kukuh dengan apa yang dipersaksikan oleh lisannya.

Setiap tingkah lakunya (Rasulullah saw.), memberikan teladan manusia sempurna, yang sesuai dengan ketetapan, serta perintah (hukum) Allah Ta'ala.

Menurut sudut pandang R.A.A. Wiranatakoesoema V, konsekuensi beriman kepada Nabi Muhammad saw. ialah memiliki kewajiban untuk mempelajari apa-apa yang ditinggalkan oleh sang utusan Allah tersebut. Tersirat bahwa tingkat keimanan seorang muslim berbanding lurus dengan tingkat keilmuannya. Semakin bertambahnya ilmu maka semakin kukuh pula keimanannya. Secara singkat, dengan memahami pengetahuan yang mendetail mengenai riwayat Rasulullah saw. yang meliputi segala aspeknya, umat Islam dapat mengambil faedah daripadanya berupa keteladanan, nasihat, hukumhukum, prinsip-prinsip, serta nilai-nilai yang dapat dijadikan pedoman terbaik bagi kehidupannya. Di sini, R.A.A. Wiranatakoesoema V menjadikan Rosulullah saw. sebagai sosok manusia sempurna tanpa celah, tanpa ada kekurangan, dan selalu benar (baik dalam perkataan, perbuatan maupun ketetapannya). Nabi Muhammad saw. menjadi poros teladan manusia yang lengkap dan istimewa. Sebagaimana yang dipaparkan oleh R.A.A. Wiranatakoesoema V, sebagai berikut:

Sagemblěngna riwajat Nabi saw. njoemponan saniskara kaboetoeh. Dina

Koerän noe 'aḍim, ngawèngkoe saniskara kapěrloean. Pěpěk sapoeratina.

Komo diboektikeun, deui toeladanana anoe dipilampahkeun koe Nabi saw.

Saintjak-intjak, andjeunna mah pitjontoeun woengkoel. Hak didamèl toeladan : andjeunna teh, hidji poetra paměgět; hidji paměgèt anoe garwaän; hidji rama tina sababaraha poetra; hidji tatangga; hidji sobat, boh dina ka sěnangan atanapi kaprihatinan; hidji soedagar; hidji anoe minggat, noe dioedag-oedag; hidji Radja; hidji Mantri karadjaän; hidji toekang ngadamèl wet; hidji jalma anoe ngadjalankeun hoekoem

${ }^{27}$ R.A.A. Wiranata Koesoema, Riwajat Kangdjeng..., hlm. v. 
pangadilan; hidji soldadoe; hidji kapala pěrang; sarěng hidji noe poerah oenggal pěrang. Andjeunna ngarandapan roepi-roepi kabalangsakan, nanging salamina oenggoel deui, anoe pětana teu katěpi koe akal manoesa. Kitoe deui Nabi Moehammad saw. teh, diangkat Rasoel, anoe sinělir di pajoeneun Allah taäla. ${ }^{28}$

\begin{abstract}
Artinya:
Seutuhnya riwayat Nabi saw. telah memenuhi segala hal yang dibutuhkan. Di dalam al-Qur'an, telah mencakup seluruh keperluan. Segala sesuatunya telah tersedia dengan lengkap. Apalagi dibuktikan, oleh teladannya yang menjalankan seluruh isi Al-Qur'an yaitu Nabi saw.

Setiap langkahnya selalu menjadi contoh. Ia adalah orang yang berhak dijadikan teladan: ia adalah seorang anak laki-laki; seorang pria yang memiliki istri; seorang ayah dari beberapa anak; seorang tetangga; seorang sahabat, baik dalam suka maupun duka; seorang saudagar; seorang yang melarikan diri, yang dikejar-kejar; seorang Raja; seorang Mantri kerajaan; seorang ahli dalam membuat peraturan dan ketentuan (hukum); seorang yang menaati hukum pengadilan; seorang prajurit; seorang panglima perang; seorang yang biasa dititah (oleh perintah Allah) berperang pada setiap peperangan. Dia telah mengalami berbagai macam kesengsaraan, namun selamanya akan unggul (menang) kembali, hal itu tidak bisa terpikirkan oleh akal manusia. Begitu pula Nabi Muhammad saw. adalah seseorang yang diangkat menjadi Rasul dihadapan Allah Ta'ala.
\end{abstract}

Dari penjelasan tersebut, R.A.A. Wiranatakoesoema $\mathrm{V}$ telah menyampaikan bahwa, Nabi Muhammad saw. adalah contoh konkret penjabaran Al-Qur' an dalam kehidupan. Beliau adalah manusia yang diangkat derajatnya setinggi-tingginya dan telah dimuliakan langsung oleh Yang Maha Mulia, Allah Swt. Berbagai peran serta pasang surut kehidupan Rasulullah saw. merupakan gambaran nyata yang akan dihadapi oleh umatnya dikemudian hari. Gambaran hidup tersebut mencakup seluruh problematika kehidupan sekaligus kunci penyelesaiannya. Inilah pelajaran berharga yang dimaksud oleh R.A.A. Wiranatakoesoema V: "...anoe pinoeh koe pěpěnděman, anoe tanpa wangěnan hargana...". ${ }^{29} \mathrm{Hal}$ ini yang menyebabkan R.A.A. Wiranatakoesoema V seketika tergugah untuk menerjemahkan karya E. Dinnet dan Sliman tanpa ragu. Dengan membaca dan mempelajari riwayat hidup Rasulullah saw. pembaca akan mendapatkan penuntun kehidupan yang membimbing manusia memegang teguh ajaran Islam. Rasulullah saw. menjadi satu-satunya manusia di muka bumi yang segala perilakunya, tutur katanya, serta ketetapannya, diimani dan diikuti oleh keturunan, para sahabat, hingga umatnya dari generasi ke generasi selama 14 abad lamanya (sampai sekarang). Hanya umat Islam yang menerapkan seluruh aspek kehidupan Nabi Muhammad saw. dalam kesehariannya. Dalam bentuk pertanyaan, R.A.A.

\footnotetext{
${ }^{28}$ R.A.A. Wiranata Koesoema, Riwajat Kangdjeng..., hlm. v.

${ }^{29}$ R.A.A. Wiranata Koesoema, Riwajat Kangdjeng..., hlm. vii.
} 
Kontribusi R.A.A. Wiranatakoesoema...... | Asep Achmad H, dkk

Wiranatakoesoema $\mathrm{V}$ mencoba membuka paradigma pembaca untuk menyadari bahwa panutan Islam adalah orang yang istimewa dan tidak tergantikan, sebagai berikut:

Tjing saha, anoe sok dipikaingèt, meh teu aja pohona, dina oesik malikna, péta-pětana; leumpangna; djantěngna; oetjapna djeung kalakoeanana? Naha, aja, anoe ditiron : karěsěpna, kaěmboengna, prak-prakan tjaritana, pèta dahar leueutna, pèta dioek nangtoengna, pèta sare djeung njaringna, datangka toeroen toemoeroen ka roendajanana ${ }^{30}$

Naha kintěn-kintěnna aja deni, djělěma di doenja ieu, anoe saniskara lakoe lampahna, pada ngabandoengan, pada noeroetan koe mangreboe-reboe djělěma? ?1 $^{31}$

Artinya:

Apakah ada, seseorang yang selalu diingat, hampir tidak pernah dilupakan, baik pergerakan tubuhnya yang lambat/perlahan maupun pergerakan tubuhnya yang berbalik secara cepat, gerak-geriknya: cara berjalannya; cara berdirinya; cara berucap serta perilakunya? Apakah ada, seseorang yang ditiru: kesukaannya, ketidak sukaannya; cara berbicaranya; cara makan dan minumnya; cara duduk dan bangkitnya; cara tidur dan bangunnya, hingga sampai pada keturunan-keturunannya?

Benarkah ada lagi manusia di dunia ini, yang seluruh tingkah lakunya diperhatikan, diikuti oleh beribu-ribu orang?

Kebiasaan hidup Nabi ini telah dicatat oleh sekitar tiga belas ribu orang, baik yang mendengar langsung sabdanya maupun yang bertatap muka dan melihat sendiri apa yang dilakukan oleh Rasulullah saw. Catatan-catatan tersebut dihimpun dan disusun menjadi kitab hadis, yang masyhur disebut dengan Kutubus Sittah atau Sahih Sittah. Bahkan, ada pula kitab yang secara khusus membahas tentang para sahabat Nabi saw. yang sekaligus berperan sebagai pencatat hadis, yakni kitab Asmaul Rijal. Buku lain yang memaparkan tentang sahabat Rasul saw. adalah buku salinan karya Ibn Hajar al-Ascalon yang berjudul 'Isaha fi tamhisa'l Sahaba. R.A.A. Wiranatakoesoema V mengutip perkataan Dr. Sprenger pada pendahuluan buku tersebut yang menyatakan bahwa: "Tidak ada suatu bangsa pun seperti kaum Muslim yang mencatat kehidupan setiap tokoh-tokoh mulia yang berilmu dan berbudi tinggi secara detail. Hingga catatan-catatan itu menjadi teladan kaum muslim generasi selanjutnya selama berabad-abad. Bila kaum Muslim tidak mengabadikan catatan-catatan tersebut, maka belum tentu keturunan-keturunannya memiliki pengetahuan tetang kehidupan kaum muslim terdahulu (terkhusus kehidupan para sahabat) yang kukuh memegang ajaran Islam". 32

Cara R.A.A. Wiranatakoesoema $\mathrm{V}$ yang secara terus menerus menyampaikan keutamaan-keutamaan Islam dapat menumbuhkan rasa cinta

\footnotetext{
${ }^{30}$ R.A.A. Wiranata Koesoema, Riwajat Kangdjeng..., hlm. vi.

${ }^{31}$ R.A.A. Wiranata Koesoema, Riwajat Kangdjeng..., hlm. vii.

${ }^{32}$ R.A.A. Wiranata Koesoema, Riwajat Kangdjeng..., hlm. vii.
} 
pembaca terhadap Islam. Lebih khusus, kaum muslim yang membacanya akan sangat bangga dengan agama yang dianutnya. Sehingga, para pembaca akan tertarik mempelajari dan membuka lembaran-lembaran buku selanjutnya yang memaparkan tentang riwayat manusia mulia Nabi Muhammad saw.

Tidak dapat dipungkiri, tidak hanya pembaca muslim saja yang akan mengonsumsi karyanya. Dapat diperkirakan, masyarakat lintas bangsa pun lintas agama yang mampu berbahasa Belanda tertarik membaca bukunya. Karya terjemah Belanda berpotensi untuk dibaca oleh orang-orang Eropa yang mayoritas merupakan kalangan non-Islam. Kekhawatiran ini membuat R.A.A. Wiranatakoesoema $\mathrm{V}$ memaparkan hal-hal dasar tentang Islam pada kata pengantarnya. Ia mengenalkan Islam dengan pembahasan awal mengenai rukun Islam pertama yang disebut syahadat, kemudian masuk pada pemahaman tauhid mengenai keimanan terhadap Allah Yang Maha Esa dan Rasul-Nya, dilanjutkan dengan ulasan keutamaan-keutamaan Islam.

Selain itu, pada akhir pemaparan, secara singkat R.A.A. Wiranatakoesoema V mengutarakan harapannya, “...teneinde de Hollandsch sprekenden in de geledenheid te stellen tot bedoelde kostbare schatten door te dringen, welke tot dusverre voor velen verborgen liggen (...pada kesempatan ini pun diharapkan agar karya ini menjadi sebuah harta karun berharga bagi diskusi-diskusi di negeri Belanda, sambil memecahkan beberapa masalah yang masih gelap)". ${ }^{33}$ Ia menjadi sosok yang ingin mengenalkan Islam secara halus tanpa perdebatan dan konflik. Ia membuka ruang intelektual, agar pembaca berkenan mempertimbangkan karyanya sebagai bacaan berharga untuk didiskusikan dalam memecahkan permasalahan atau pemahaman mengenai Islam ataupun Nabi Muhammad saw. yang mungkin belum terpecahkan.

Berbeda dengan apa yang disampaikan pada edisi Belanda, pada edisi Sunda R.A.A. Wiranatakoesoema V menekankan tentang pentingnya memperhatikan, mengulang, mengingat serta mempelajari riwayat Rasulullah saw. Sasaran pembaca yang di tujukan adalah Suku Sunda yang mayoritas menganut agama Islam. "Pěrjogi oerang Pasoendan aroeninga ka riwajat Panoetan Islam, anoe paměrědihna dilampahkeun lima kali dina sadintěn sawěngi (Penting bagi masyarakat Pasundan untuk mengetahui riwayat Panutan Islam, yang perintah ibadahnya dilakukan lima kali dalam sehari)". ${ }^{34}$ Upaya penerjemahan ini tidak lain adalah bukti kecintaan R.A.A. Wiranatakoesoema V terhadap Islam dan masyarakat Pasundan. Tekadnya untuk berdakwah adalah tanggung jawab besar yang diembannya sebagai pemimpin muslim. Dengan karyanya, ia berharap umat muslim di Tatar Sunda memiliki akses bacaan untuk mempelajari riwayat panutan Islam. Agar di

\footnotetext{
${ }^{33}$ R.A.A. Wiranata Koesoema, Het Leven..., hlm. viii.

${ }^{34}$ R.A.A. Wiranata Koesoema, Riwajat Kangdjeng..., hlm. vii.
} 
Kontribusi R.A.A. Wiranatakoesoema....... | Asep Achmad H, dkk

kemudian hari, masyarakat Pasundan tidak henti meneladani serta menerapkan ajaran Rasulullah saw. dalam kehidupan kesehariannya.

\section{Kontribusi R.A.A. Wiranatakoesoema V Dalam Menerjemahkan Sejarah Nabi saw.}

Proses menerjemahkan identik dengan kemampuan bahasa yang dimiliki oleh seorang penerjemah. Bagaimana sikap penerjemah ketika mengalih bahasakan bahasa sumber ke dalam bahasa sasaran sesuai dengan struktur leksikal maupun gramatikal bahasa sasaran serta kebudayaannya ${ }^{35}$ dengan meminimalisir tingkat perubahan bentuk teks aslinya. Buku Riwajat Kangdjeng Nabi Moehammad saw. diterjemahkan ke dalam bahasa Sunda dengan dua paduan bentuk penulisan, yakni penulisan dalam bentuk prosa yang diuraikan secara narasi dalam paragraf-paragraf yang tidak terikat oleh aturan apapun dan penulisan dalam bentuk puisi tradisional Sunda yang ditulis secara narasi berdasarkan kaidah-kaidah tertentu. R.A.A. Wiranatakoesoema $\mathrm{V}$ menghadirkan karya terjemahan baru yang dibangun dalam dua bentuk penulisan berbeda. Penulisan dalam bentuk prosa merupakan pola mengulang penulisan karya asli, berbeda dengan penulisan bentuk puisi yang dilakukan sebagai upaya adaptasi budaya masyarakat pembaca. Peneliti akan menguraikan kedua bentuk penulisan karya terjemah R.A.A. Wiranatakoesoema V dalam buku Riwajat Kangdjeng Nabi Moehammad saw., sebagai berikut

\section{Penerjemahan dalam bentuk prosa}

Hal menarik yang mendominasi penulisan bentuk prosa ialah ketika R.A.A. Wiranatakoesoema $\mathrm{V}$ mengekspresikan karya terjemahannya dengan menggunakan tata krama bahasa Sunda yang lazim disebut undak usuk basa, sebuah perbendaharaan bahasa Sunda yang tidak dimiliki oleh bahasa sumber (Inggris). Undak usuk basa merupakan suatu sistem penggunaan ragam bahasa Sunda berdasarkan tingkatan yang meliputi basa lemes (bahasa halus), basa sédéng (pertengahan), dan basa loma (akrab/kasar). Tingkatan bahasa ini bersangkut paut dengan kekuasaan, kedudukan atau status sosial, dan keakraban atau hubungan peran pembicara dengan lawan bicara. ${ }^{36}$

Tumbuh suburnya etika bahasa ini telah dipengaruhi oleh undak usuk, tingkat tutur, krama inggil, atau speech levels bahasa Jawa. Ajip Rosyidi berpendapat bahwa pada era Kerajaan Sunda seperti masa Pajajaran, bahasa Sunda adalah bahasa yang sangat egaliter dan demokratis, tidak ada perbedaan kasta dan regional. Namun, di tahun-tahun terakhir abad ke-16, bahasa Sunda

\footnotetext{
${ }^{35}$ Moh. Supardi, Dinamika Penerjemahan Sastra: South of The Slot, (Jakarta: Buletin AlTuras Mimbar Sejarah, Sastra, Budaya, dan Agama, Vol. XXIII No. 2, Juli 2017), hlm. 381.

${ }^{36}$ Karna Yudibrata, dkk, Bagbagan Makena Basa Sunda, (Bandung: Rahmat Cijulang, 1990), hlm. 135-136.
} 
tua yang egaliter mulai dihilangkan. Kemudian pada tahun 1872, pemerintah kolonial Belanda membakukan etika bahasa ini sebagai bahasa standar di wilayah Keresidenan Jawa Barat yang diberlakukan di lingkungan pemerintahan dan kaum menak pribumi. ${ }^{37}$ Sehingga pada awal abad ke-20 bahasa Sunda telah berbentuk kasta-kasta ketatabahasaan. R.A.A. Wiranatakoesoema V yang lahir pada tahun 1888 pun tumbuh di lingkup keluarga menak yang fasih menggunakan undak usuk basa.

Buku Riwajat Kangdjeng Nabi Moehammad saw. yang terbit menjelang pertengahan abad ke-20 menggunakan penulisan bahasa Sunda yang kental dengan undak usuk basa. Tingkat tutur yang digunakan menghadirkan perbedaan nilai rasa dalam berbahasa antara karya terjemah dengan karya aslinya. Namun, perbedaan ini tidak mengubah makna atau gagasan yang disampaikan oleh bahasa asli, melainkan memberikan pemahaman mendalam terhadap pemilik bahasa sasaran. Sebagai contoh, peneliti akan memaparkan uraian narasi berikut:

Sasoemping-soemping ka boemi, Nabi saw. ngaboedjěng garwana Siti Chadidja, bloek njoeöeh kana lahoenanana, salirana ngělěpěr sepěrti noe keur moeriang nirisan „Geuwat simboetan! Geuwat simboetan!'Rentjang-rentjangna raboel maroeroe, nga-lingkung andjeunna bari njimboetan, doegi ka lělěrna. Siti Chadidja kaget, pok toemaros: ,Koe naon, rama Qasim teh, atoeh? Abdi teh ngadjoeroengan sababaraha oerang, sina mapagkeun, tapi maranehna warangsoel deui, teu těpang sarěng gamparan; diteang ka Hira teu aja; dipilari ka manamana loeareun kota, teu méndak bedja-bedja atjan". ${ }^{38}$

Paragraf tersebut menguraikan tentang peristiwa kepulangan Rasulullah saw. paska wahyu pertama turun. Pemaparan berlanjut dalam bentuk percakapan antara beliau dengan istrinya, Khadijah, lengkap dengan deskripsi situasi serta kondisi lahir dan batin yang dialaminya. Uraian kejadian ini memperlihatkan bahwa, R.A.A. Wiranatakoesoema V dengan leluasa menggunakan tata krama bahasa Sunda. Ia menarasikan peristiwa ini melalui basa lemes, yakni tata bahasa yang digunakan kepada orang yang dihormati, yang memiliki kedudukan atau tingkat sosial yang lebih tinggi. Contoh basa lemes yang terkandung pada teks tersebut ialah kata sumping (datang), bumi (rumah), ngabujeng (menemui), garwa (istri), salirana (tubuhnya), rencang (teman), gamparan (anda), anjeun (beliau) dan lainnya. ${ }^{39}$ Kata-kata ini pun mempunyai padanan kata pada basa loma dan basa sédéng, diantaranya:

\footnotetext{
${ }^{37}$ E. Zaenal Arifin, Bahasa Sunda Dialek Priangan, Jurnal Pujangga Vol. 2 No. 1, Juni 2016, hlm. 13-14, 2.

${ }^{38}$ R.A.A. Wiranata Koesoema, Riwajat Kangdjeng..., hlm. 33.

${ }^{39}$ Jajang A Rohmana, Sundanese Sira in Indonesia Archipelago: A Contribution of R.A.A. Wiranatakoesoema's Riwajat Kangdjeng Nabi Moehammad saw., (Bandung: Jurnal Al-Albab Vol. 6, No. 1, Juni 2017), hlm. 40.
} 
Kontribusi R.A.A. Wiranatakoesoema...... | Asep Achmad H, dkk

\begin{tabular}{|l|l|l|}
\hline \multicolumn{1}{|c|}{ Basa Loma } & \multicolumn{1}{c|}{$\begin{array}{c}\text { Basa Sedeng } \\
\text { (lemes jang sorangan) }\end{array}$} & $\begin{array}{c}\text { Basa Lemes } \\
\text { (lemes jang batur) }\end{array}$ \\
\hline Cunduk, datang & Dongkap & Sumping, rawuh \\
\hline Imah & Rorompok & Bumi \\
\hline Jugjug & Bujeng & Bujeng \\
\hline Pamajikan & Bojo & Garwa \\
\hline Awak & Awak & Salira \\
\hline Batur & Rencang & Rencang \\
\hline Maneh & - & Anjeun \\
\hline
\end{tabular}

Meskipun ketiganya memiliki arti yang sama, namun nilai keindahan serta tingkat tutur bahasanya berbeda. Di sini, penerjemah memilih menggunakan kata-kata bermakna sangat sopan, untuk menghormati serta mengagungkan sosok Nabi Muhammad saw. Ia menggunakan kata gamparan yakni panggilan kepada orang yang sangat dihormati, kata ini tergolong ke dalam basa lemes pisan (bahasa yang sangat halus). Melalui tata bahasa ini, tanpa diberitakan sekalipun, pembaca akan memahami bahwa tokoh Muhammad ialah seseorang yang dihormati, berkedudukan luhur, atau menempati strata sosial tinggi. Percakapan ini pun menggambarkan secara nyata bagaimana komunikasi yang dilakukan oleh masyarakat Sunda. Pertanyaan Khadijah yang menanyakan keadaan Rasulullah saw. disisipkan kata-kata penegas khas Sunda, seperti kata teh, atuh, mah, nya, dan sebagainya: "Koe naon, rama Qasim teh, atoeh?" (Apa yang terjadi, wahai ayah Qasim?). Penuturan gaya bicara orang Sunda ini begitu mencerminkan bagaimana khazanah berbahasa di tatar Sunda (nyunda). ${ }^{40}$ Ada pun pengaruh kosakata asing, seperti kosakata bahasa Arab dan Belanda juga ditemukan pada karya ini. Seiring dengan masuknya Islam ke Nusantara, termasuk ke daerah Sunda di Jawa Barat, maka kosakata bahasa Arab kian banyak masuk ke dalam perbendaharaan kosakata Sunda. Kata-kata ini selanjutnya tidak dirasakan lagi sebagai kosakata serapan, seperti kata tafakoer, takaboer, tawěkal, elmoe, rědjěki, adzan, doenja, kalboe, masdjid, djaman, halal, moenapek, dan lain sebagainya. Sedangkan pengaruh bahasa Belanda terdapat pada penggunaan kata wet (hukum, peraturan, undang-undang) ketika menerjemahkan kata the laws (hukum) dan kata legislator (pembuat undangundang) diterjemahkan sebagai toekang ngadaměl Wet (pembuat undangundang).$^{41}$ Hal ini terjadi karena pengaruh bangsa Belanda di pemerintahan. Penerjemah menguraikan pula status sosial masyarakat Mekah dengan

\footnotetext{
40 Jajang A Rohmana, Sundanese Sira, hlm. 40.

${ }^{41}$ R.A.A. Wiranata Koesoema, Riwajat Kangdjeng..., hlm. 195,223; E. Dinet dan Sliman Ben Ibrahim, The Life of Mohammad, hlm. 121,150.
} 
menggunakan sistem feodal masyarakat Priangan yang berlaku pada masa kolonial Belanda, seperti paragraf berikut:

Kira-kira aja lima wèlas santana bangsa Quraisj, ngadareuheusan sorangan ka Nabi saw., toeloej arasoep Islam, nyaeta: 'Oethmān ibnoe 'Affān; 'Abdoer Rahman 'ibnoe Aoef; Oeba ida ibnoe l Hārith; Dja'far ibnoe 'Abì Thalib djeung lian ti eta. ${ }^{42}$

Artinya:

Kurang lebih ada lima belas orang santana kaum Quraisy, menghadap dengan sendirinya kepada Nabi saw., yang kemudian masuk Islam, yaitu: Utsman ibnu Affan; Abdurrahman ibnu Auf; Ubaida ibnu ak-Harits; Ja'far ibnu 'Abi Thalib dan yang lainnya.

R.A.A. Wiranatakoesoema $\mathrm{V}$ menerjemahkan the leading men of the Quraish tribe (pemimpin kaum Quraisy) ${ }^{43}$ dengan santana bangsa Quraisj (santana kaum Quraisy). Ia menggolongkan para sahabat Rasul saw. sebagai santana yang dalam hirarki status sosial masyarakat Sunda merupakan masyarakat kelas menengah. Ia pun menggolongkan orang-orang terkemuka sebagai kaum menak yang memiliki kedudukan tinggi di kota Mekah, seperti menerjemahkan kata the most townsmen (orang-orang yang paling masyhur di Mekah) dengan kata menak Mekah ${ }^{44}$ menerjemahkan status Khadijah dari kata $a$ rich and noble widow (seorang janda kaya nan ningrat) menjadi hidji randa menak, anoe katjida beungharna (seorang janda ningrat yang tidak terhingga kekayaannya), ${ }^{45}$ kemudian menempatkan Abdul Muthalib, kakek Rasulullah saw. sebagai menak tertinggi dari seluruh kaum menak Quraisy dengan menerjemahkan kata a most noble tribe (bangsawan tertinggi kaum Quraisy) dengan golongan pang menakna (menak tertinggi kaum Quraisy). ${ }^{46}$ Dengan kata lain, penerjemah menerapkan tingkat kebangsawanan berdasarkan gelar atau strata sosial yang lumrah di kalangan orang Sunda pada masa itu.

R.A.A. Wiranatakoesoema $\mathrm{V}$ pun menggunakan basa loma untuk menerjemahkan peristiwa-peristiwa yang melibatkan orang-orang berstrata sosial rendah, seperti rakyat jelata dan hamba sahaya. Penerjemah memilih kata manehna (dirinya) sebagai panggilan bagi orang yang memiliki status sosial di bawah kaum santana, misalnya ketika mengisahkan sosok Halimah,

\footnotetext{
${ }^{42}$ R.A.A. Wiranata Koesoema, Riwajat Kangdjeng..., hlm. 40.

${ }^{43}$ E. Dinet dan Sliman Ben Ibrahim, The Life of Mohammad, (Paris: The Paris Book Club, 1918), hlm. 28.

${ }^{44}$ R.A.A. Wiranata Koesoema, Riwajat Kangdjeng..., hlm. 50; E. Dinet dan Sliman Ben Ibrahim, The Life of Mohammad, hlm. 34; Jajang A Rohmana, Sundanese Sira, hlm. 40-41. ${ }^{45}$ R.A.A. Wiranata Koesoema, Riwajat Kangdjeng..., hlm. 18; E. Dinet dan Sliman Ben Ibrahim, The Life of Mohammad, hlm. 14.

${ }^{46}$ R.A.A. Wiranata Koesoema, Riwajat Kangdjeng..., hlm. 5; E. Dinet dan Sliman Ben Ibrahim, The Life of Mohammad, hlm. 4.
} 
ibu susu Nabi: ...manehna katoet Harith salakina, ngabudjěng Nabi saw., njoehoenkeun dilěbětkeun kana golongan Moe'min (...dirinya beserta Harits suaminya, menemui Nabi saw., memohon agar dimasukkan ke dalam golongan Mukmin). ${ }^{47}$ Penggunaan basa loma pada kata salakina (suaminya) pada teks tersebut menegaskan tentang persamaan status sosial keduanya yang berasal dari kalangan rakyat biasa.

Basa loma juga dipergunakan untuk menegaskan ekspresi kemarahan seseorang. Seperti situasi yang dialami Umar bin Khattab ketika tersinggung oleh perkataan buruk Jamil ibn Ma'mar yang menghina dirinya yang telah menjadi muslim. Kalimat "Thou liest!" pada karya asli diterjemahkan menjadi "Ngabohong silaing!". ${ }^{48}$ Keduanya memiliki arti "Engkau berdusta!" namun penggunaan kata thou menjadi silaing memberi kesan negatif, karena kata silaing pada konteks ini merupakan bahasa kasar yang digunakan untuk merendahkan lawan bicara. Sehingga emosi yang dialami oleh Umar diterjemahkan pula melalui emosi yang terkandung dalam kebiasaan bahasa masyarakat Sunda.

Babasan (ungkapan/kiasan) atau paribasa (peribahasa) merupakan salah satu kebiasaan berbahasa dalam masyarakat Sunda, yang diungkapkan secara lisan maupun tulisan. Peribahasa sebagai ungkapan tradisional dibuat sebagai petuah serta nasihat yang disampaikan secara tersirat dengan memperhatikan estetika bahasa yang tinggi. Unsur tersebut diwariskan secara turun-temurun dengan struktur dan makna yang sama, memiliki aturan baku yang tetap yang bertujuan untuk menjaga nilai-nilai budaya yang terkandung di dalamnya agar tidak berubah. ${ }^{49}$ Munculnya peribahasa dalam bahasa Sunda bisa diakibatkan oleh sifat umum orang Sunda yang tidak berani berbicara langsung pada tujuan utamanya, dengan maksud agar tidak menyinggung perasaan serta menghargai lawan bicara. ${ }^{50}$ Beberapa peribahasa Sunda pun menghiasi karya terjemah Dalem Haji, beliau banyak menerjemahkan ungkapan bahasa Inggris ke dalam istilah-istilah, maupun ungkapan-ungkapan serta peribahasa yang melekat di Tatar Sunda.

Oelah ditioeng parantos hudjan, bilih gamparan kadoehoeng, teu ngadangoe pioendjoek abdi. ${ }^{51}$

Artinya:

\footnotetext{
${ }^{47}$ R.A.A. Wiranata Koesoema, Riwajat Kangdjeng..., hlm. 40.

${ }^{48}$ R.A.A. Wiranata Koesoema, Riwajat Kangdjeng..., hlm. 68; E. Dinet dan Sliman Ben Ibrahim, The Life of Mohammad, hlm. 44.

${ }^{49}$ Siti Kodariah dan Gugun Gunardi, Nilai Kearifan Lokal dalam Peribahasa Sunda: Kajian Semiotika, (Bandung: Jurnal Patanjala Vol. 7 No. 1, Maret 2015), hlm 114.

${ }^{50}$ Yayat Sudrayat, Ulikan Semantik Sunda, (Bandung: CV. Geger Sunten, 2003), hlm. 97.

${ }^{51}$ R.A.A. Wiranata Koesoema, Riwajat Kangdjeng..., hlm. 10, paragraf 4, baris 10; E. Dinet dan Sliman Ben Ibrahim, The Life of Mohammad, hlm. 9, paragraf 1, baris 6-8.
} 
Ulah ditiung parantos hujan, khawatir engkau menyesal, tidak mendengarkan petunjuk saya.

Kalimat tersebut merupakan penggalan percakapan antara Halimah dan Aminah. Saat itu Halimah datang membawa Nabi Muhammad saw. yang telah menyelesaikan masa menyusui untuk mengembalikannya kepada Aminah. Namun, rasa kasih sayang Halimah kepada Rasul membuat Halimah khawatir dengan keadaan Rasul yang baru berusia 2 tahun yang harus tinggal di kota yang suasana alamnya berbahaya bagi kesehatan balita. Sehingga ia meminta agar Aminah mempertimbangkan pendapatnya agar ia bisa kembali membawa Rasul ke Badya, demi kesehatan sang anak. Peribahasa "Ulah ditiung parantos hujan (Jangan menggunakan payung setelah turun hujan)" mengandung nasehat agar "Jangan berhati-hati setelah mengalami hal buruk". Dalem Haji memilih ungkapan ini untuk menyampaikan pesan tersirat dari Halimah agar Aminah mempertimbang-kan keputusannya dengan baik supaya suatu saat nanti dia tidak menyesalinya.

Peristiwa lain yang mangandung peribahasa dalam bentuk petuah ialah saat para prajurit Islam dengan menyesal mengungkapkan kesalahannya yang secara tergesa-gesa memutuskan hal tanpa terlebih dahulu mempertimbangkan masak-masak pendapat Rasulullah saw. Mereka berkata: "We ought to have bowed down to thy judgment (Kami seharusnya tunduk patuh kepada keputusan mu)"; "ieu abdi-abdi sadajana ngaraos kadoehoeng, moengpang kana piwédjang gamparan, roemaos moeroegoel, kirang pamilih, hěnteu dibeuweung dioetahkeun heula (Kami semua menyesal, tidak patuh terhadap nasihat engkau, merasa egois dengan keinginan sendiri, kurang pertimbangan, henteu dibeuweung diutahkeun heula)". ${ }^{52}$ Penambahan ungkapan "henteu dibeuweung diutahkeun heula" memiliki makna tidak memikirkan masak-masak, memutuskan sesuatu tanpa pertimbangan mendalam sehingga berbuah penyesalan.

Menurut Budi Rahayu Tamsyah, peribahasa merupakan bentuk kalimat (klausa) yang sangat dekat dengan hati yang mengungkapkannya. ${ }^{53}$ Jika dianalisis, kedua peribahasa tersebut mencerminkan nilai kearifan lokal masyarakat Sunda yang mengajarkan untuk selalu bertindak hati-hati dalam memutuskan sebuah perkara, agar keputusan yang dipilih tidak merugikan dirinya sendiri maupun orang lain di kemudian hari. Sehingga dari sudut pandang orang Sunda, orang yang bijaksana dalam mengambil keputusan adalah orang yang akan selamat di waktu mendatang. Nasihat ini lahir dari pengalaman-pengalaman yang dialami oleh leluhur yang kemudian

\footnotetext{
${ }^{52}$ E. Dinet dan Sliman Ben Ibrahim, The Life of Mohammad, hlm. 83, paragraf 8, baris 3; R.A.A. Wiranata Koesoema, Riwajat Kangdjeng..., hlm. 135, paragraf 1, baris 8-9.

${ }^{53}$ Siti Kodariah dan Gugun Gunardi, Nilai Kearifan..., hlm. 116.
} 
disampaikan secara turun-temurun agar keturunannya tidak terjerumus dalam kesalahan yang sama.

Dengan demikian, penggunaan peribahasa menjadi akses komunikasi yang tepat untuk mengungkapkan peristiwa-peristiwa yang terjadi dalam kehidupan Nabi Muhammad saw. Selain itu, sasaran pembaca yang mayoritas masyarakat Sunda akan lebih mampu mengambil pelajaran dari setiap kisah yang disampaikan, karena adanya kedekatan emosional dengan bahasa yang digunakan. Seperti ungkapan peribahasa yang ditujukan kepada istri Abu Lahab: "Awewe tukang ngelek suluh atawa biwir nyiroe rombengeun". R.A.A. Wiranatakoesoema $\mathrm{V}$ menerjemahkan carrier of fire wood menjadi awewe tukang ngelek suluh (wanita pembawa kayu bakar) yang merupakan ungkapan Al-Qur'an yang bermakna wanita penyebar fitnah. ${ }^{54}$ Kemudian, menambahkan peribahasa "biwir nyiroe rombengeun" yakni peribahasa yang ditujukan kepada seseorang yang senang menceritakan apapun termasuk hal yang seharusnya dirahasiakan, seperti perbuatan istri Abu Lahab yang senang menyebarkan kagorengan (hal-hal buruk). Peribahasa ini mengandung unsur miawak dan mibarang. Miawak ialah pengungkapan yang menggunakan bagian tubuh manusia, sedangkan mibarang pengungkapan yang menggunakan barang atau alat-alat yang biasa digunakan oleh masyarakat Sunda. Dalam peribahasa ini, mulut diumpamakan sebagai wadah yang rusak atau bocor, karena apapun yang disimpan ke dalam wadah pasti akan jatuh berserakan, seperti halnya mulut yang tidak bisa menjaga perkataannya. Sehingga orang yang tidak dapat menjaga mulutnya dipandang buruk sifatnya pun rusak akhlaknya.

Terdapat pula peribahasa yang mengandung unsur misato yakni pengungkapan yang menggunakan istilah hewan. Penggunaan peribahasa ini terdapat pada peristiwa kekalahan yang dialami orang-orang Mekah ketika memerangi umat Islam di perang Badar. Ketika itu, banyak dari prajurit kaum kafir yang melarikan diri dari peperangan. R.A.A. Wiranatakoesoema V menerjemahkan kalimat: The fugitives were considered to be coward deserting before the battle had begun (orang-orang yang melarikan diri dianggap sebagai pengecut yang kabur sebelum pertempuran dimulai) menjadi Sakoer noe malaboer tea, beak koe pamojok; disarěboet hayam lisoeng, koemeok eleh koe bikang (semua orang yang kabur itu, habis-habisan dicerca; disebut hayam lisung, kumeok eleh ku bikang). ${ }^{55}$ Makna dari hayam lisung ialah ayam yang jinak yang tidak pernah berkeliaran jauh dari pekarangan rumah, istilah ini juga sering diperuntukkan bagi orang yang pemalu yang tidak memiliki keberanian kuat. Peribahasa ini menerangkan tentang sikap

${ }^{54}$ E. Dinet dan Sliman Ben Ibrahim, The Life of Mohammad, hlm. 33, paragraf 5, baris 3; R.A.A. Wiranata Koesoema, Riwajat Kangdjeng..., hlm. 50, paragraf 3, baris 3-4.

${ }^{55}$ E. Dinet dan Sliman Ben Ibrahim, The Life of Mohammad, hlm. 79, paragraf 6, baris 2-3; R.A.A. Wiranata Koesoema, Riwajat Kangdjeng..., hlm. 129, paragraf 3, baris 3-4. 
prajurit yang kabur sebagai pengecut yang tidak memiliki keberanian untuk berperang. Bahkan, kata kumeok eleh ku bikang (kalah dari ayam betina) bermakna bahwa tingkat keberanian mereka berada di bawah keberanian kaum yang lebih lemah. Dengan demikian, ungkapan ini benar-benar merendahkan perilaku yang dilakukan oleh para prajurit yang lari meninggalkan pertarungan saat perang belum dimulai. Di sini, selain memiliki nilai-nilai petuah, peribahasa pun berperan untuk menggambarkan bagaimana sikap, tingkah laku, serta perbuatan manusia.

Peribahasa digunakan pula untuk mengungkapkan keadaan seseorang, misalnya pada peristiwa ketika Maisara menemui Rasulullah saw. untuk menawarkan maksud Khadijah yang ingin diperistri oleh beliau, maka Rasul menjawab: "Kaoela teh, lieuk euweuh ragap taja". ${ }^{66}$ Makna denotasi peribahasa ini ialah ketika kita berpaling ke kanan maupun ke kiri kita tidak menemukan apa-apa, begitu pula saat meraba dengan tangan, tak ada sesuatu pun yang kita dapatkan. Peribahasa ini mengungkapan keadaan Rasulullah saw. yang tidak memiliki apa-apa (sangat miskin), seperti kiasan yang ditulis pada karya asli yang menyatakan bahwa "My hands are empty (Kedua tangan saya kosong)" yang bermakna tidak memiliki sesuatu apapun untuk diberikan. ${ }^{57}$

Pada kisah lainnya, peribahasa pun mengungkapkan keadaan kaum muslim pada detik-detik kedatangan bala tentara musuh ketika perang parit: "Saěnjana harita teh, tagiwoer, riweuh; ngan Moeslimin noe sadjati těngtrěm; ajem, itba ka Rasoeloellah, teu oenggoet kalindoean, teu gědag kaanginan, tembong kapoendjoelanana (Sebenarnya pada saat itu, terjadi kehebohan, tidak karuan; hanya Muslimin yang sejatinya merasa tentram; tenang, itiba kepada Rasulullah, teu unggut kalindungan, teu gedag kaanginan, terlihat keunggulannya)" ${ }^{58}$ Istilah ini menggambarkan ketetapan hati dan kuatnya pendirian, bagaikan daun yang tidak bergerak meski angin menerpanya. Meskipun kaum Muslim dihadapkan dengan berbagai cobaan, namun, kehadiran Rasulullah saw. menenangkan hati mereka sehingga meneguhkan pendiriannya serta bertambah pula keimanannya. Sosok Rasul saw. diposisikan sebagai tonggak penguat kaum Muslim yang mampu menentramkan umatnya dalam keadaan genting dan membangun kepercayaan diri para mujahid Islam.

Berikut peneliti akan menuliskan beberapa babasan dan paribasa Sunda yang menghiasi karya terjemah ini:

1. ...noenggěllis (sebatang kara). ${ }^{59}$

\footnotetext{
${ }^{56}$ R.A.A. Wiranata Koesoema, Riwajat Kangdjeng..., hlm. 22, paragraf lanjutan dari hlm. 21, baris 4 .

${ }^{57}$ E. Dinet dan Sliman Ben Ibrahim, The Life of Mohammad, hlm. 17, paragraf 3, baris 3.

${ }^{58}$ R.A.A. Wiranata Koesoema, Riwajat Kangdjeng..., hlm. 157, paragraf 2, baris 1-3.

${ }^{59}$ R.A.A. Wiranata Koesoema, Riwajat Kangdjeng..., hlm. 16, paragraf 10, baris 3.
} 
2. ...kenging tjarios ti oenggal djělěma, jen Sajid Moehammad djadi sabiwir hidji, diparoedji sae laku lampahna, pertjajaeun. ${ }^{60}$ Makna konotasi jadi sabiwir hiji ialah menjadi bahan pembicaraan orang lain.

3. Andjeunna dipikarěsěp koe oenggal djělěma. Oenggal djělěma pada hajang těrang, katarik koe amis budi, hade basa djeung balaka. ${ }^{61}$ Amis budi menjadi ungkapan yang mengandung pandangan hidup orang Sunda terhadap pribadi manusia, kata kiasan ini mencerminkan seseorang yang memiliki akhlak baik, bertutur kata baik, serta ramah.

4. ...datang sieun liwat saking, boeloe poendoek maroeringkak, boedjoer kokoplokan tarik..$^{62}$ Istilah ini menggambarkan keadaan manusia ketika merasakan ketakutan yang luar biasa. Karena merasa terlampau takut hingga bulu punduknya berdiri, tubuhnya gemetar.

5. ...ngagoedag lir seneu hoeroeng (berkobar bagaikan api yang menyalanyala). ${ }^{63}$

6. Harita mah koering ngaraos kabina-bina njěrina. Aja paripaos, njolok mata boentjělik. ${ }^{64}$ Arti nyolok mata buncelik ialah mencolok mata yang terbelalak. Ungkapan ini biasa diucapkan ketika orang lain berlaku buruk (menyakiti hati) seseorang di hadapan orang tersebut.

7. Rasoeloellah saw. moepakat kana timbanganana Sajid Abu Bakar, malah andjeunna miwědjang, sangkan landoeng aisan, wadjib diadjenan sapěrti ka sasama. $^{65}$ Peribahasa ini mencerminkan kebijaksanaan dalam memutuskan perkara. Landing aisan bermakna timbang rasa. Pada konteks ini, kaum Muslim mempertimbangkan perasaan hati para tawanan perang dengan memperlakukan mereka seperti sesama.

8. Djaoeh-djaoeh pandjang gagang, wiwirang di kolong tjatang. ${ }^{66}$ Makna yang tersirat dari peribahasa ini ialah sudah jauh-jauh datang namun tidak mendapat apa-apa, sehingga merasa sangat malu karena diketahui oleh orang lain.

9. ...sono palaj ningali těmpat bali geusan ngajadi. ${ }^{67}$ Ungkapan bali geusan ngajadi merupakan kata yang diucapkan untuk tempat asal atau tanah kelahiran.

10. ...herang tjaina beunang laoekna. ${ }^{68}$ Peribahasa ini mencerminkan kearifan lokal orang Sunda terhadap sesama manusia. Makna ungkapan ini

\footnotetext{
${ }^{60}$ R.A.A. Wiranata Koesoema, Riwajat Kangdjeng..., hlm. 18, paragraf 5, baris 2-4.

${ }^{61}$ R.A.A. Wiranata Koesoema, Riwajat Kangdjeng..., hlm. 19, paragraf 3, baris 5-6.

${ }^{62}$ R.A.A. Wiranata Koesoema, Riwajat Kangdjeng..., hlm. 31, paragraf 7, baris 4-5.

${ }^{63}$ R.A.A. Wiranata Koesoema, Riwajat Kangdjeng..., hlm. 34, paragraf 1, baris 1-3.

${ }^{64}$ R.A.A. Wiranata Koesoema, Riwajat Kangdjeng..., hlm. 72, paragraf 3, baris 16-17.

${ }^{65}$ R.A.A. Wiranata Koesoema, Riwajat Kangdjeng..., hlm. 126, paragraf 4, baris 2.

${ }^{66}$ R.A.A. Wiranata Koesoema, Riwajat Kangdjeng..., hlm. 134, paragraf 3, baris 14-15.

${ }^{67}$ R.A.A. Wiranata Koesoema, Riwajat Kangdjeng..., hlm. 180, paragraf 2, baris 4-5.

${ }^{68}$ R.A.A. Wiranata Koesoema, Riwajat Kangdjeng..., hlm. 198, paragraf 5, baris 2-3.
} 
ialah mendapatkan hasil tanpa menyakiti orang lain (maksud tercapai tanpa terjadi kerusakan). Kata-kata ini mengandung petuah agar seseorang yang hendak menggapai tujuannya menggunakan cara-cara yang baik yang diibaratkan oleh herang caina (bening airnya), yakni jalan/cara yang baik sebersih dan sebening air mineral.

Berbagai peristiwa yang disampaikan menggunakan babasan maupun paribasa memiliki nilai rasa bahasa mendalam karena mengandung pandangan hidup masyarakat Sunda. R.A.A. Wiranatakoesoema V merealisasikan tujuannya untuk menghadirkan karya sejarah Rasulullah saw. dalam bahasa yang dekat dan akrab dengan masyarakat Pasundan. Ia menghadirkan Islam berdampingan dengan bahasa lokal. Selain menambah penghayatan pembaca, karya ini pun berperan melestarikan ungkapan tradisional Sunda yang kini mulai menghilang eksistensinya.

\section{Penerjemahan dalam bentuk dangding}

Pola kedua ialah penulisan terjemah dalam bentuk dangding. Dangding atau guguritan merupakan puisi terikat yang tumbuh dalam tradisi sastra Sunda sebagai salah satu hasil pergaulan budaya antara masyarakat Sunda dengan masyarakat Jawa. Pada awalnya, tradisi ini merupakan karya sastra tulis Jawa-Mataram yang berkembang sekitar abad ke-17. ${ }^{69}$ Menurut Ajip Rosidi, dangding adalah ikatan puisi tertentu yang melukiskan hal-hal tertentu pula, dibangun oleh beberapa pola puisi yang disebut pupuh. Salmun berpendapat, bahwa pupuh merupakan tujuh belas macam aturan untuk membuat dangding. ${ }^{70}$ Ketujuh belas pupuh tersebut ialah empat pupuh Sekar Ageung (Asmarandana, Dangdanggula, Kinanti, Sinom), dan tiga belas pupuh Sekar Alit (Pangkur, Durma, Maskumambang, Ladrang, Magatru, Mijil, Pucung, Wirangrong, Gurisa, Balakbak, Gambuh, Jurudemung, dan Lambang). Masing-masing aturan ini memiliki nama serta karakteristik yang terikat oleh guru lagu (bunyi vokal akhir pada setiap baris), guru wilangan (jumlah suku kata pada setiap baris) dan jumlah baris (padalisan) pada setiap baitnya ( $p a d a) .{ }^{71}$ Pada dasarnya, teks dangding digubah oleh seorang bujangga untuk pembaca yang bersenandung, sehingga teks dangding tidak dibaca

\footnotetext{
${ }^{69}$ Hawe Setiawan, sebuah esai berjudul: Dangding Mistis Haji Hasan Mustapa, Sumber: salihara.org Kalam 28/2016, Diakses pada 31 Juli 2018; Jajang Arahmana, Sastra Sufistik Sunda dan Peneguhan Identitas Islam Lokal: Kontribusi Dangding Haji Hasan Mustapa (1853-1930), (Bandung: UIN Sunan Gunung Djati, t.t), hlm. 29.

70 Suwardi Alamsyah P. dan Herry Wiryono, Pengungkapan Nilai Budaya Wawacan Amungsari-Lembusari, (Bandung: Departemen Pendidikan dan Kebudayaan, Direktorat Jenderal Kebudayaan, Balai Kajian Sejarah dan Nilai Tradisional Jawa Barat, 1995), hlm. 3.

${ }^{71}$ Suwardi Alamsyah P., dkk, Analisis Struktur Sajarah Carita Lampahing Para Wali Kabeh, (Bandung: Departemen Pendidikan dan Kebudayaan, Direktorat Jenderal Kebudayaan, Balai Kajian Sejarah dan Nilai Tradisional, 1999/2000), hlm. 10-11.
} 
seperti membaca bacaan biasa (baik dengan bersuara maupun membaca dalam hati) melainkan untuk dinyanyikan. ${ }^{72}$

R.A.A. Wiranatakoesoema $\mathrm{V}$ menerbitkan serta menyusun sebuah karya terjemah berbentuk prosa yang dihiasi lebih dari 700 bait dangding. Karyanya tergolong ke dalam karya sejarah yang menguraikan riwayat hidup Nabi Muhammad saw., dilengkapi dengan karya terjemah ayat-ayat Al-Qur'an yang terikat oleh dangding. Buku Riwajat Kangdjeng Nabi Moehammad saw. ini mengandung 109 buah dangding, 34 buah dangding berupa uraian sejarah dalam bentuk narasi dan 75 buah dangding berupa terjemahan ayat-ayat AlQur'an. Setiap dangding diberi nama sesuai dengan nama pupuh yang membentuk karakternya.

R.A.A. Wiranatakoesoema $\mathrm{V}$ tidak menggunakan seluruh aturan pupuh melainkan memilih 9 pola dari 17 pola pupuh. Kesembilan pola tersebut ialah 44 dangding dengan pupuh Asmarandana, 34 dangding berpupuh Sinom, 14 dangding menggunakan pupuh Kinanti, 4 buah dangding berpupuh Magatru, 2 buah dangding dengan pola Mijil dan Pangkur, sedangkan penggunaan pupuh Dangdanggula, Durma, serta Maskumambang masingmasing berjumlah 1 dangding. Adapun bentuk puisi di luar pola pupuh, yakni penulisan 6 buah dangding dalam bentuk Kidung. Kidung yang dimaksud merupakan sebuah karangan berbentuk sajak bebas berpola 8 suku kata setiap lariknya. Karya puisi tradisional Sunda ini menyebar pada setiap bab dengan jumlah berbeda-beda pun menggunakan pola pupuh yang bervariasi. Meski tidak bisa disampaikan satu persatu, peneliti akan memaparkan beberapa dangding hasil penerjemahan dari bentuk prosa dan ayat-ayat Al-Qur'an. Berikut adalah salah satu contoh dangding yang digunakan sebagai ekspresi kesedihan serta tangisan:

\section{Maskoemambang}

Sipat-sipat kaajä̈n Kangdjěng Nabi, katrangan mantoena, noe djěněngan Sayid 'Ali, něrangkeun ahlak-ahlakna:

Rasoeloellah aděg-panganděgna ramping, těgěp salirana, potonganana pinilih, sarta djangkoengna meudjeuhna.

Mastakana ageung djeung ramboetna galling, tjangkěr paromanna, matak hebat noe ningali, damis lěměs kandèl roembah.

Sotja ageung sarta hideung dikoeriling, koe boeloe sotjana, parandjang sarta tjarěntik, djadi woewoeh katěgěpan. ${ }^{73}$

Artinya:

\footnotetext{
${ }^{72}$ Moriyama Mikihiro, Semangat Baru: Kolonialisme, Budaya Cetak, dan Kesastraan Sunda Abad ke-19, (Jakarta: Kepustakaan Populer Gramedia, 2005), hlm. 54, 57; A. Tisnawerdaja, Widjining Sastra, Cet. II, (Kuningan: Famtis, 1956), hlm. 49; Hawe Setiawan, sebuah esai berjudul: Dangding Mistis Haji Hasan Mustapa, sumber: salihara.org (Kalam 28/2016), diakses pada 31 Juli 2018.

${ }^{73}$ R.A.A. Wiranata Koesoema, Riwajat Kangdjeng..., hlm. 241, bait: 1-3,5.
} 
Sifat-sifat keadaan Kanjeng Nabi, keterangan menantunya, yang bernama Sayid Ali, menerangkan akhlak-akhlanya:

Rasulullah posturnya ramping, tubuhnya tegap, bagian-bagiannya terbaik, serta tingginya tidak terlalu tinggi dan tidak terlalu pendek.

Kepalanya besar dan rambutnya ikal, raut mukanya kencang (tidak kendur), yang melihat akan kagum, pipinya halus jenggotnya tebal.

Matanya besar serta hitam, dikelilingi bulu mata, panjang dan lentik, sehingga bertambah ketampanannya.

R.I. Adiwidjaja menerangkan bahwa maskumambang berarti emas yang pipih atau tipis. Diartikan pula oleh M.A. Salmun sebagai "emas ngambang", yaitu emas yang tidak tenggelam tapi terapung. Kata kambang, ngambang, memiliki arti terapung di permukaan air. Setiap bait pupuh Maskumambang berjumlah empat larik dengan metrum 12i, 6a, 8i, 8a. Pupuh ini bersifat prihatin, bersedih hati, tangisan, derita, serta sesambat. ${ }^{74}$ Hanya ada satu buah dangding berpupuh Maskumambang dalam karya terjemah ini. Secara seksama, dangding ini mengikuti aturan penulisan pupuhnya tanpa mengubah pola vokal akhir maupun jumlah suku kata setiap larik. Mayoritas dangding yang ada pada karya terjemah ini ditulis dalam bentuk paragraf dengan tanda koma sebagai simbol yang membedakan antara larik satu dengan larik selanjutnya, sehingga satu paragraf dihitung satu bait. Beberapa dangding lain ditulis sebagaimana penulisan bait puisi pada umumnya, yakni setiap larik disusun ke bawah tanpa membentuk sebuah paragraf.

Pupuh Maskumambang dipilih sebagai wadah ekspresi untuk mengenang sosok Rasulullah saw. yang telah wafat, baik ciri-ciri fisiknya, akhlaknya, juga kebiasaannya saat sedang sedih, kesal, marah, ataupun bahagia. Kenangan-kenangan inilah yang membuat kaum Muslim merasa begitu kehilangan sosok pemimpin sekaligus keluarga yang kasih sayangnya tercurah limpah kepada umatnya. Sehingga perpisahan menjadi momen paling menyedihkan yang membuat hati menderita dan membuat pandangan berderai air mata. Keselarasan antara karakter pupuh dengan pesan yang ingin disampaikan oleh penerjemah, akan menghidupkan emosi pembaca dan penghayatan mendalam. Selain pupuh Maskumambang, pupuh Dangdanggula dan Mijil pun menghiasi peristiwa-peristiwa yang berwatak sedih.

Pupuh Dangdanggula berasal dari kata dendang (kawih, nyanyian) dan gula. Dangdanggula, berarti kawih manis, nyanyian yang manis, yang indah. Pupuh ini berwatak kesenangan, kegembiraan, kebanggaan, serta menggambarkan keagungan. Seiring perkembangan Tembang Sunda, karakternya tidak hanya sebatas itu, namun menggambarkan pula watak

\footnotetext{
${ }^{74}$ Ma'mur Danasasmita, Sastra Sunda Lama, Jilid II, (Kabupaten Bandung: Penerbit Kelir, 2011), hlm. 31.
} 
kesedihan. Jumlah lariknya 10, lumrah disebut pupuh 10 dengan aturan 10i, 10a, 8e/o, 7u, 9i, 7a, 6u, 8a, 12i, 7a. ${ }^{75}$

\section{Dangdanggoela}

Totondena djalma noe sinelir, anoe kenging noegraha Pangeran, siang wengi tara towong, karesep njingkoer ti batoer, milih tempat noe soeni soeni, Moehammad kitoe lampahna, tjalik dinoe singkoer, maksad ngaroetjat salira, njoektjroek galoer, kamoeljaan noe sadjati njirnakeun atma djeung soekma.

Těngah peuting noedjoe djěmplang-djěmpling, ladjěng angkat ngantoenkeun garwana, ngadjoegdjoeg těmpat noe simpe, taja djalma noe loemakoe, angkat njatjat dina Sagara keusik, anoe makplak satoengtoeng tingal, taja noe ngaganggoe, sato hewan keur talibra, estoe djěmpling, taja sora noe kakoeping, ngan bentang anoe baranang.

Nadjan tempat noe anggang ti nagri, resep betah manahna soegema henteu aja noe ngarewong, ari ajeuna dirioeng, tingkah polah soelaja ti misti, taladjakna oerang Mekah, noekangkeun karoehoen, nirtja kalakoeanana, resep njembah kana djieunna pribadi, njimpang tina Agama.

Loba pisan anoe sasar pikir, lampah sasab njembah anoe salah, henteu moehit ka Jang Manon, njembah ka kajoe ka batoe, Ka'ba pinoeh koe noe sok dipoedji, anoe sok dipoendjoeng dipoedja, titinggal karoehoen, beunang njarieun manehna, moemoel njembah titinggal Nabi Ibrahim, sakitoe hareupeunana.

Maranehna djadi djalma moesjirik, bengkok sembah teu toehoe ka Allah koe artja-artja kagelo, Berhala noe tina batoe, noe disangka kawasa toer sakti, tjara keur dina djamanna, bedja ti karoehoen, dioegoeng-oegoeng disembah, noekang nonggong ka sesembahan noe wadjib, Allah ta 'ala noe Toenggal. ${ }^{76}$

Artinya:

Tanda-tanda orang yang terpilih, yang mendapat anugrah Tuhan, setiap siang malamnya tidak pernah tenang, hal yang disukainya menjauh dari keramaian, memilih tempat yang sunyi sepi, seperti itulah tingkah laku Muhammad, duduk jauh dari khalayak, bermaksud untuk merenungkan diri, menelaah alur, kemuliaan yang sejati menghapus atma dan sukma.

Tengah malam ketika sunyi-sunyinya, pergi meninggalkan istrinya, mencari tempat yang sepi, tidak ada orang lain yang bepergian, berangkat berjalan kaki di atas Padang pasir, yang datar serta luas sepanjang mata memandang, tidak ada yang mengganggu, hewan-hewan tertidur nyenyak, benar-benar sunyi, tidak ada suara yang terdengar, hanya bintang yang bercahaya terang.

Meskipun berada di tempat yang jauh dari negeri, hatinya bahagia karena tidak ada yang mengganggu, namun sekarang dirinya dikelilingi, oleh perilaku ingkar, orang Mekah, yang membelakangi leluhur, tercela kelakuannya, suka menyembah kepada apa yang dibuat oleh dirinya, menyimpang dari agama.

Banyak (diantara mereka) yang pola pikirnya keliru, tingkah lakunya sesat menyembah yang salah, tidak percaya kepada Yang Maha Memberi Petunjuk, menyembah ke kayu dan batu, Kakbah dipenuhi oleh benda-benda yang suka dipuji, yang selalu dihormati dan dipuja, peninggalan nenek moyang, hasil

${ }^{75}$ Ma'mur Danasasmita, Sastra Sunda..., hlm. 25.

${ }^{76}$ R.A.A. Wiranata Koesoema, Riwajat Kangdjeng..., hlm. 25, bait: 1,2,4,13,14. 
buatan mereka sendiri, enggan menyembah peninggalan Nabi Ibrahim, meskipun ada di hadapannya.

Mereka menjadi musyrik, bengkok sesembahan tidak setia kepada Allah tertipu oleh berhala-berhalanya, berhala yang terbuat dari batu, yang disangka memiliki kekuatan serta kesaktian, adat yang diturunkan oleh nenek moyang, diagung-agung disembah, membelakangi sesembahan yang wajib, Allah ta'ala yang Tunggal.

Pada karya terjemah ini, hanya ada satu-satunya dangding berpupuh Dangdanggula. Dangding tersebut ditemukan pada bagian ketiga, bercerita tentang kesedihan Rasulullah saw. atas perilaku ingkar masyarakat Mekah yang menganut paganisme. Tergambar berbagai ekspresi watak pupuh Dangdanggula pada dangding tersebut, selain kesedihan pupuh ini menggambarkan hal yang paling menggembirakan hati (ngagambarkeun nu pangbungah-na). ${ }^{77}$ R.A.A. Wiranatakoesoema $\mathrm{V}$ menerjemahkan kalimat: How did he pass his time? Allah had inspired him with the love of solitude, and Mohammad loved more than anything to wander all alone on great empty plains stretching away farther than the eye could reach (Bagaimana dia melalui waktunya? Allah telah mengilhami dirinya dengan rasa cinta pada kesunyian, dan Muhammad sangat suka bepergian seorang diri lebih dari apapun, di tanah luas yang sangat sepi, terus menjauh hingga melebihi jangkauan penglihatan mata), dengan dua bait pertama dangding-nya, yang menggambarkan hal yang paling dicintai oleh Rasulullah saw. adalah menyendiri dalam melakukan pengembaraan diri untuk menyepi, bertafakur. Dengan begitulah Nabi merasa sangat dekat dengan Sang Maha Pencipta, hatinya mendapat ketenangan dan kebahagiaan yang luar biasa. ${ }^{78}$

Pada dangding Dangdanggula ini pun mengekspresikan keagungan dan kebanggaan. Penerjemah mengagungkan perilaku Rasul yang tidak henti mengagung-agungkan Allah Yang Maha Esa, Rasul pun memiliki kebanggaan terhadap agama yang dibawa oleh leluhurnya Nabi Ibrahim a.s., ada pula berhala-berhala yang diagung-agungkan oleh orang-orang Mekah, mereka pun membangga-banggakan warisan nenek moyangnya dan menyembah sesembahan yang mereka buat oleh tangannya sendiri. Sedangkan, pada bagian akhir dangding tergambar kesedihan Rasulullah saw. yang melihat fenomena yang terjadi pada kaumnya. Dapat dikatakan, bahwa sifat dangding mampu mendukung suasana peristiwa yang terkandung didalamnya. Begitu pula pada dangding berpupuh Mijil, sebagai berikut:

\section{Midjil}

Moesoeh ngoempoel hatena moeringis, soekoe leungeun djěblog, toetoempakan koeda onta oge, tjarapeëun oeroetna kamari, ngabelaän diri, njingkahan pakewoeh.

\footnotetext{
${ }^{77}$ A. Tisnawerdaja, Widjining Sastra..., hlm. 52.

${ }^{78}$ E. Dinet dan Sliman Ben Ibrahim, The Life of Mohammad, hlm. 21.
} 
Beak karěp soesah reudjeung sědih, tanaga meh pohpol, bisa handjat koe hese beleke, taneuh djěblog tjampoer oejah asin, tjotjoba Jang Widi, ka djalma moeroegoel. ${ }^{79}$

Artinya:

Musuh berkumpul hatinya meringis, kaki dan tangannya berlumpur, tunggangannya kuda dan unta pun demikian, mereka kelelahan akibat peristiwa kemarin, membela diri, menyingkirkan kesulitan.

Sekuat tenaga (melewati) kesulitan dan kesedihan, agar tenaga-nya habis, mereka datang dengan sangat sukar, lumpur bercampur asin, cobaan dari Yang Maha Mengetahui, kepada orang-orang yang memaksakan kehendak.

Merujuk pada pendapat M.A. Salmun, Mijil berasal dari kata bijil yang artinya keluar, dahulu pupuh ini disebut Raras Ati. Pupuh ini terdiri atas enam baris dengan pola $10 \mathrm{i}, 6 \mathrm{o}, 10 \mathrm{e}, 10 \mathrm{i}, 6 \mathrm{i}, 6 \mathrm{u} .{ }^{80}$ Dangding tersebut ditulis sesuai dengan aturan pupuh Mijil. Peristiwa yang disampaikan ialah mengenai kesusah-payahan musuh Islam yang bersikukuh untuk melakukan perjalanan menuju medan pertempuran saat Perang Badar. Kala itu, Allah Swt. menurunkan hujan, kemudian jalur yang harus mereka lewati menjadi sangat licin dan berlumpur, alhasil, mereka telah kelelahan sebelum melakukan perang. Kesedihan, kesulitan, serta celaka tergambar jelas pada dangding ini. Seperti yang dikemukakan oleh Danasasmita bahwa berkarakter pupuh Mijil ialah sedih, sunyi, sepi, celaka, bingung, serta susah.

Dangding-dangding bercorak sedih ini memiliki kesamaan dan perbedaan. Jika Maskumambang menggambarkan (prihatin, sedih hati, tangisan, derita, dan sesambat), maka Dangdanggula mengekspresikan dua hal yang berbeda yakni kesedihan dan kegembiraan bahkan keagungan serta kebanggaan. Lain lagi dengan Mijil yang lebih bersifat sedih namun menerangkan kesunyian, kebingungan, kesusahan pun celaka. R.A.A. Wiranatakoesoema V menempatkan ketiganya pada masing-masing peristiwa yang selaras dengan karakteristik pupuhnya, sehingga setiap dangding memerankan kisah yang berbeda dengan ungkapan emosi yang berbeda pula meskipun sama-sama bertema kesedihan.

Menurut Tisnaderwaja, pupuh Kinanti pun memiliki watak prihatin (sedih), keprihatinan yang dimaksud adalah kesedihan yang dialami akibat rasa saling mencintai. ${ }^{81}$ Prihatin diartikan pula sebagai tawakal. Kinanti berasal dari kata anti yang berarti dago (lemesna antos) yang artinya tunggu, bisa pula berasal dari kata kanti yang artinya bersama. Secara umum, pupuh ini bersifat penantian juga harapan, terdiri dari enam larik dengan aturan $8 u$,

\footnotetext{
${ }^{79}$ R.A.A. Wiranata Koesoema, Riwajat Kangdjeng..., hlm. 118, bait: 1,2.

${ }^{80}$ Ma'mur Danasasmita, Sastra Sunda..., hlm. 32.

${ }^{81}$ A. Tisnawerdaja, Widjining Sastra..., hlm. 51.
} 
8i, 8a, 8i, 8a, 8i. ${ }^{82}$ Oleh sebab itu, dangding Kinanti sesekali ditemukan berdampingan dengan dangding berpupuh Asmarandana.

Secara etimologis, kata Asmarandana berasal dari bahasa Sansekerta, terdiri dari dua suku kata yakni smara (cinta) dan dhana (api). Sehingga, Asmarandana memiliki arti api cinta. Tidak berbeda dengan namanya, pupuh Asmarandana memiliki karakter yang bersifat asmara, saling kasih mengasihi, cinta mencintai. Aturan metrum pupuh ini terdiri dari tujuh larik yang berpola 8i, 8a, 8e/o, 8a, 7a, 8u, 8a. ${ }^{83}$ Biasanya, R.A.A. Wiranatakoesoema V mengubah pola tujuh suku kata (7a) menjadi delapan suku kata (8a). Berikut contoh dangding hasil terjemahan dari satu tema peristiwa yang menggunakan dua bentuk pupuh berbeda yaitu Asmarandana dan Kinanti:

\section{Asmarandana}

Ningali sagara keusik, pandita heměng manahna, naha gara-gara naon, aja mega bodas leumpang, siga manoek keur ngalajang, majoengan onta keur madjoe, ngaleut ngeungkeuj diioehan.

Hěnteu lila mega leungit, lantaran aja gantina, dahan kai noe marènol, daoenna pating aroelang, siga anoe ngagoepajan, ngabageakeun noe rawoeh, tjarondong hajang dirampa.

Majoengan anoe keur tjalik, anděkak handapeunana, moerangkalih noe keur ngaso, srangenge eukeur mantjèran, manah pandita teu samar, boeboehan pinoeh koe elmoe, tangtoe aja noe dirahmat.

Noe diraksa koe Jang Widi, diantara djalma-djalma, aja kakasih Jang Manon, tjotjog saoenggěling Kitab, jen di achir baris medal, Nabi kakasih Jang Agoeng, panoetan sakabeh djalma.

Bahīrà moedoen ti pasir, marentah ka badegana, ampar-ampar sing bareres, djeung sadia katoeangan, leueutan sapoeratina, rek ngahormat anoe rawoeh, tatamoe anoe oetama. ${ }^{84}$

Artinya:

Melihat padang pasir, pendeta merasa heran, ada sebab apa, awan putih berjalan, bagaikan burung yang sedang melayang, menaungi unta yang sedang maju, berduyun-duyun bersama rombongannya dilindungi dari cahaya matahari.

Tidak lama awan pun menghilang, karena sudah ada gantinya, dahan kayu yang marěnol, daunnya saling mengayun, bagaikan melambai-lambai, mengucapkan rasa rindu terhadap yang baru datang, dedaunannya merunduk seperti ingin dijamah.

Menaungi yang sedang duduk, duduk bersila di bawahnya, seorang anak kecil yang sedang beristirahat, matahari sedang terik, pikiran pendeta tidak samar, penuh dengan ilmu, tentu ada yang dirahmat.

Yang dilindungi oleh Yang Maha Mengetahui, diantara orang-orang, ada kekasih Yang Maha Pemberi Petunjuk, sesuai dengan yang dituturkan Kitab, bahwa di akhir akan muncul, Nabi kekasih Yang Maha Agung, panutan seluruh manusia.

\footnotetext{
${ }^{82}$ Ma'mur Danasasmita, Sastra Sunda..., hlm. 28.

${ }^{83}$ Ma'mur Danasasmita, Sastra Sunda..., hlm. 23.

${ }^{84}$ R.A.A. Wiranata Koesoema, Riwajat Kangdjeng..., hlm. 15-16, bait: 4,6,7,8,9.
} 
Kontribusi R.A.A. Wiranatakoesoema...... | Asep Achmad H, dkk

Bahira berjalan menuruni pasir, memerintahkan pelayannya, untuk menggelar tikar-tikar dengan rapi, serta menyiapkan makanan, minuman selrngkap-lengkapnya, akan menghormati yang baru datang, tamu yang paling utama.

\section{Kinanti}

Moehammad pamitan moendoer, doemadak kěrsa Jang Widi, palaj ngebrehkeun katrangan, nembongkeun saksi noe jakin, beuheung djoebahna ngaliglag, koe Bahira katingali.

Dina Kitab geus disěboet, tjitjiren Nabi pinilih, geus make tjap Kanabian, dina walikat geus pasti, di lébah bagal poendakna, pandita teu samar deui.

Pajoeneunana geus tangtoe, manoesa anoe sinelir, kakasih Allah ta'ala, baris ngagem pangkat Nabi, noe didago ti baheula, waktoe ieu enggeus lahir. ${ }^{85}$

Artinya:

Muhammad pamit mundur, tiba-tiba Yang Maha Mengetahui, ingin memberi keterangan, memperlihatkan saksi yang yakin, kerah jubah (Muhammad) terbuka, oleh Bahira terlihat.

Di dalam Kitab telah disebutkan, ciri-ciri Nabi yang terpilih, telah memiliki cap Kenabian, sudah dipastikan ada pada belikatnya, di bagian bawah pundaknya, pendeta tidak ragu lagi.

Di hadapannya sudah tentu, manusia yang terpilih, kekasih Allah ta'ala, yang akan mendapat gelar Nabi, yang ditunggu sejak lama, sekarang telah lahir.

Kedua dangding ini mengisahkan tentang pertemuan antara Rasulullah saw. dengan pendeta Bahira. Bahira benar-benar menguasai kandungan sebuah kitab yang berisi ramalan kedatangan seorang nabi pada masyarakat Arab. Dia merasa yakin nabi tersebut akan datang pada masa hidupnya. Sebagaimana yang disampaikan pada dangding Asmarandana, Bahira terbiasa melihat kedatangan kafilah Mekah yang singgah tidak jauh dari biaranya, tetapi perhatiannya terpaku pada gumpalan awan putih yang menaungi seseorang diantara para musafir dari kafilah itu. Tiba-tiba perhatiannya berubah menjadi kekaguman, karena saat mereka berhenti, awan itu pun berhenti dan menggumpal di atas pohon yang di bawah pohon itulah mereka berteduh. Bahira memiliki firasat bahwa diantara mereka telah hadir seorang nabi yang selama ini diramalkan dalam kitab yang dibacanya: “...diantara djalma-djalma, aja kakasih Jang Manon, tjotjog saoenggěling Kitab, jen di achir baris medal, Nabi kakasih Jang Agoeng, panoetan sakabeh djalma". Untuk menyambut kedatangan tamu agung tersebut, Bahira menyuguhkan seluruh persediaan makanan dan minuman yang dimilikinya.

Dangding Asmarandana ini menceritakan tentang kekasih Allah Swt., Allah melindungi Rasul-Nya dari panas terik matahari melalui naungan awan putih serta memberikan keteduhan di bawah rindangnya dedaunan. Diceritakan pula

\footnotetext{
${ }^{85}$ R.A.A. Wiranata Koesoema, Riwajat Kangdjeng..., hlm. 16-17, bait: 15-17.
} 
wujud cinta Bahira kepada Rasul, ia mengeluarkan seluruh makanan dan minuman yang ia miliki untuk menyambut kedatangan sang Nabi.

Pada dangding Kinanti, diceritakan pula bahwa Bahira telah merasa yakin bahwa Muhammad adalah seorang nabi, setelah tak sengaja melihat tanda kenabian diantara kedua punggungnya: "Pajoeneunana geus tangtoe, manoesa anoe sinelir, kakasih Allah ta'ala, baris ngagem pangkat Nabi, noe didago ti baheula, waktoe ieu enggeus lahir". Bait ini menunjukkan penantian panjang Bahira yang menunggu kedatangan Nabi Allah, Muhammad saw. Sehingga karakter kedua pupuh ini selaras dengan peristiwa yang sedang dikisahkan. Pada bab empat pun dangding Asmarandana dan Kinanti menceritakan satu peristiwa mengenai Isra' Mikraj:

\section{Asmarandana}

Sanggeus langit toedjoeh lapis, kaliwatan sadajana, teu pisan ngaraos tjape, waktosna ngan sakoteap. Ladjěng aja dadangoean, gěretna Kalam Loh Mahfoed, noeliskeun papasten djalma.

Malaikat raong moedji, reang maraos salawat, ngahormat anoe nëmbe djol, kakasihna Noe Kawasa, ginoeloeran kanoegrahan, sinělir koe Maha Agoeng, ngěrsakeun djongok patěpang. ${ }^{86}$

Artinya:

Setelah tujuh lapis langit, terlewati seluruhnya, tidak sekalipun terasa lelah, waktu berlalu dalam sekejap. Lalu terdengar, suara geratan Loh Mahfuz, menuliskan tentang takdir manusia.

Malaikat raung memuji, terdengar (banyak) suara para malaikat membaca salawat, menghormati yang baru datang, kekasih Yang Maha Kuasa, gelar keanugrahan, yang dipilih oleh Yang Maha Agung, memberikan kesempatan bertemu langsung.

\section{Kinanti}

Watěs eta Nabi Rasoel, ngagěm andělan pribadi, angkat njorang hidjabhidjab, hidjabna lalangse gaib, Gaiboellah noe disědja, Katoenggalan Maha Soetji.

Moeka hidjab noe panoetoep, pěrtela Gaibing Goesti. Moal kahontal koe akal, moal kaběrik koe harti, leungit daja djeung oepaja, sirna Rasa dina Batin. $^{87}$

Artinya:

(Setelah sampai) di batas itu Nabi Rasul, mengandalkan diri sendiri, pergi melewati hijab-hijab, hijabnya (berupa) tirai gaib, Gaibullah yang dimaksud, ke-Esaan Yang Maha Suci.

Membuka hijab yang terakhir, perincian tentang Tuhan Yang Gaib. Tidak akan terjangkau oleh akal, tidak akan terkejar oleh pikiran, tidak ada daya dan upaya, hilang rasa dalam jiwa.

\footnotetext{
${ }^{86}$ R.A.A. Wiranata Koesoema, Riwajat Kangdjeng..., hlm. 75-76, bait: 9,10.

${ }^{87}$ R.A.A. Wiranata Koesoema, Riwajat Kangdjeng..., hlm. 76, bait: 1,2.
} 
Kedua dangding tersebut mengandung peristiwa dimana tertumpah ruah kasih sayang Allah kepada Rasul-Nya. Allah menjalankan Rasul melewati tujuh lapis langit dengan kecepatan cahaya tanpa sedikit pun membuat Rasul kelelahan. Pada dangding Asmarandana tergambar kebahagiaan serta rasa cinta para malaikat atas kedatangan Rasul, mereka memuliakannya dengan bersalawat. Dangding Kinanti pun memaparkan bahwa Rasul diundang untuk bertemu langsung dengan Allah, Dzat yang selalu ia cintai dan ia nantikan perjumpaan dengan-Nya.

Pada bab lima, pupuh Asmarandana digunakan pula dalam penerjemahan sebuah lagu yang dinyanyikan oleh para pemuda Yastrib dan hamba sahaya ketika Rasulullah saw. telah menentukan tempat persinggahannya di Madinah. Karena lagu ini adalah ekspresi kecintaan masyarakat Madinah kepada Rasulullah saw. dan Rasul pun mencintai mereka, maka pupuh yang digunakan ialah pupuh Asmarandana yang memiliki watak saling mencintai serta kasih-mengasihi. Terjadi beberapa penambahan kata dalam proses penerjemahannya. Penambahan-penambahan ini dilakukan untuk melengkapi aturan baku pupuh Asmarandana, sehingga kata yang ditambahkan tidak mengubah maksud yang terkandung di dalamnya. lagu yang dinyanyikan pada karya asli berbunyi: "Muhammad hath come! The Prophet of Allah hath come to our town! (Muhammad telah datang! Nabi utusan Allah telah datang di kota kita!)", dan diterjemahkan ke dalam bentuk dangding yang berbunyi:

\section{Asmarandana}

Moehammad anoe panilih, geus rawoeh ka těmpat oerang. Oetoesan Goesti Jang Manon, baris toemětěp di oerang, ngaběrkahan tanah oerang, moegi-moegi pandjang-poendjoeng, salamět peuting djeung beurang! ${ }^{88}$

Artinya:

Muhammad manusia pilihan, telah tiba di tempat kita. Utusan Tuhan Yang Maha Memberi Petunjuk, akan menetap di kita, memberikan keberkahan kepada tanah kita, semoga selamanya, selamat setiap malam dan siang!

Dari 44 buah dangding Asmarandana, hanya 4 buah dangding yang menerjemahkan kejadian-kejadian secara narasi, sedangkan 40 dangding lainnya pun ditulis secara narasi namun dalam bentuk terjemah ayat-ayat AlQuran. Terlepas dari karakteristik peristiwa yang disampaikan, Al-Quran adalah petunjuk kehidupan sekaligus mukjizat yang diturunkan kepada Rasulullah saw. sebagai wujud cinta kasih Allah Swt. terhadap hamba-hambaNya. Sehingga tidak mengherankan jika R.A.A. Wiranatakoesoema V memilih menggunakan pupuh Asmarandana lebih banyak dari pupuh lainnya untuk mengungkapkan cinta yang disampaikan Allah Swt. melalui firman-

\footnotetext{
${ }^{88}$ R.A.A. Wiranata Koesoema, Riwajat Kangdjeng..., hlm. 97, bait: 1,2.
} 
firman-Nya, berikut beberapa contoh karya terjemahan Al-Quran dalam bentuk dangding Asmarandana:

\section{Asmarandana}

Pek, lěnjěpan masing jakin! Kalawan Asma Pangeran, anoe ngadjadikeun maneh; asri ngadjadikeunana, gětih satetes asalna; lěnjěpan datangka mafhoem, Pangeran teh pangmoeljana.

Noe geus masihan pangarti, ngadjarkeun noelis koe qalam, ngadjar manoesa sakabeh noe manehna teu těrang...(XCVI: 1-5 $)^{89}$

Artinya:

Bacalah dengan yakin! Dengan (menyebut) nama Tuhanmu, yang menciptakan mu; asri menciptakannya, dari setetes darah asalnya; bacalah hingga mafhum, Tuhan-lah Yang Maha Mulia.

Yang telah memberikan pemahaman, mengajarkan menulis dengan pena, mengajarkan manusia apa yang tidak diketahuinya... (QS. Al-'Alaq [96]: 1-5)

\section{Asmarandana}

Énjana kami ningali, njata ka wadjah andika, anoe ka langit keur měntjrong, koe hal eta ti ajeuna, Kami ngadjadikeun Qiblat, anoe andika panoedjoe, pek ngiblat ka Baetoellah.

Djeung dimana bae tjitjing, tětěpkeun wadjah andika, ngiblat teh ka dinja bae, djeung sakabeh djalma-djalma sakoer noe narima Kitab, maranehna tangtoe maphoem, eta anoe saěnjana. (II: 144) $)^{90}$

Artinya:

Sesungguhnya Kami melihat, dengan jelas kepada wajahmu (Muhammad), yang sedang menengadah ke langit, maka kini, Kami jadikan Kiblat, (ke tempat) yang kamu tuju, maka berkiblatlah ke Baitullah.

Dan dimana pun kamu berada, hadapkanlah wajahmu, berkiblat kea rah itu, dan orang-orang yang menerima Kitab (Taurat dan Injil), tentu paham, bahwa (pemindahan kiblat) itu adalah sebuah kebenaran. (QS. Al-Baqarah [2]: 144)

Kedua dangding ini menerangkan ayat yang menyampaikan tentang perintah Allah Swt. kepada Rasul-Nya. QS. Al-Alaq ayat 1-5 merupakan wahyu pertama yang Rasulullah saw. terima serta perintah pertama yang memintanya untuk iqra (membaca). Sedangkan, QS. Al-Baqarah ayat 144 ini adalah perintah untuk mengubah arah kiblat ke Baitullah (Kakbah). Tidak hanya itu, pada bab keenam ditemukan sebuah ayat yang berisi nasihat yang ditulis dalam bentuk dangding berpupuh Asmarandana:

\section{Asmarandana}

Lamoen giliran geus něpi, rek moelangkeun ka-teungeunah, bales koe noe sapagodos, reudjeung kanjěri andika, tapi moen andika sabar, aloesna teh ěnggeus poegoeh, moenggoeh djalma noe soeměrah. (XVI: 126) ${ }^{91}$

\footnotetext{
${ }^{89}$ R.A.A. Wiranata Koesoema, Riwajat Kangdjeng..., hlm. 32, bait: 1,2.

${ }^{90}$ R.A.A. Wiranata Koesoema, Riwajat Kangdjeng..., hlm. 100, bait: 1,2.

${ }^{91}$ R.A.A. Wiranata Koesoema, Riwajat Kangdjeng..., hlm. 146, bait: 1.
} 
Artinya:

Jika telah tiba giliranmu, untuk memberikan balasan atas perbuatan yang menykitimu, maka balaslah dengan yang setimpal, dengan rasa sakit mu, namun jika kamu bersabar, sesungguhnya itu lebih baik, menjadi orang-orang yang berserah diri (kepada Allah). (QS. An-Nahl [16]: 126)

Ayat ini turun setelah Perang Uhud berakhir. Rasa sedih yang menimpa Rasulullah saw. ketika mengetahui bahwa jasad pamannya, Hamzah, telah dirusak oleh Hindun membuat Rasulullah saw. merasa terlampau marah. Lalu mengatakan: "Oepama Allah taäla ngěrsakeun... Kaoela soempah, hajang malěs njěri leuwih ti kieu (Jika kelak Allah ta'ala menghendaki... Saya bersumpah, akan membalasnya dengan yang lebih menyakitkan dari ini -dalam Martin Lings disebutkan bahwa Rasul bersumpah untuk merusak tiga puluh wajah mayat kaum Quraisy-)." ${ }^{92}$ Namun, wahyu ini segera turun dan Rasulullah saw. membatalkan sumpahnya kemudian melarang keras setiap tindakan merusak muka mayat pada setiap kali peperangan berakhir.

Peristiwa kekejaman yang dilakukan oleh Hindun diabadikan oleh penerjemah dalam sebuah dangding berpupuh Durma. Setelah jasad Hamzah ditemukan, Hindun memotong hidung, telinga, serta organ tubuh lainnya. kemudian mengajak wanita yang lain untuk memotong serta menyayat-nyayat jasad kaum Muslim. Mereka melepas perhiasannya dan menggantungkan potongan-potongan tubuh kaum Muslim sebagai kalung, anting-anting, serta gelang kakinya. Hindu juga memakan, menggigit, dan mengunyah sebagian hati Hamzah dan memuntahkan sebagian lainnya. ${ }^{93}$ Lalu berdiri di atas bongkahan batu sambil menyanyikan lagu kemenangan:

\section{Doerma}

Geus kabalěs kanjěri kami ajeuna, teu poho beurang peuting, waktoe pěrang Badar, teu atjan soegěma, moen tatjan males kanjěri, kami loegina rasakeun pamalěs kami.

Moal poho kami teh salalawasna, nadjan nemahan pati, iklas ngabelaän, samemeh laksana, moelangkeun kanjěri kami, ingět ka paba, kitoe deui kadang wargi.

Noe maraot koe panggawe arandika, poho ka koelawargi, baraja sorangan, geus dilawan pěrang, lantaran ěnggeus kalindih, njembah noe anjar, ninggalkeun noe dipigoesti. ${ }^{94}$

Artinya:

\footnotetext{
92 R.A.A. Wiranata Koesoema, Riwajat Kangdjeng..., hlm. 145; Martin Lings, Muhammad: Kisah Hidup Nabi Berdasarkan Sumber Klasik, Cet. XV, (Jakarta: PT. Serambi Ilmu Semesta, 2014), hlm. 298.

${ }^{93}$ R.A.A. Wiranata Koesoema, Riwajat Kangdjeng..., hlm. 144; Martin Lings, Muhammad: Kisah..., hlm. 294-295.

${ }^{94}$ R.A.A. Wiranata Koesoema, Riwajat Kangdjeng..., hlm. 144, bait: 1,2,3.
} 
Sekarang sudah terbalas penderitaan saya, setiap siang dan malam tak pernah lupa, peristiwa perang Badar, tidak akan tenang, sebelum membalaskan dendam, saya tenang (senang) rasakanlah pembalasan saya.

Selamanya saya tidak akan pernah lupa, meskipun bertemu dengan ajal, ikhlas mempertahankan, sebelum terlaksana, membalas sakit hati saya, ingat kepada ayah, juga seluruh keluarga. Yang meninggal karena perbuatan kalian, melupakan kerabat, saudara sendiri, telah diperangi, gara-gara tergantikan, (oleh) sembahan yang baru, (hingga) meninggalkan yang dituhankan (sebelumnya).

Hanya ada satu dangding berpupuh Durma dalam karya terjemah ini. Menurut M.A. Salmun, durma memiliki arti harimau. Pupuh Durma biasanya digunakan untuk menggambarkan keadaan yang sedang berperang, terdiri dari tujuh larik yang diatur oleh kaidah 12a, 7i, 6a, 7a, 8i, 5a, 7i. Karakter pupuh ini ialah marah, penuh emosi, bertengkar, berkelahi, konflik, permusuhan, serta suasana perang. ${ }^{95}$ Saat itu Hindun melampiaskan dendam atas kematian ayahnya ketika Perang Badar. Dengan biadab ia memotong dan memakan bagian tubuh Hamzah. Pada karya asli, Hindun diumpamakan seperti hiena, seekor anjing hutan yang sangat buas, pemakan bangkai dan daging: "Like a filthy hyena, she squatted on Hamzah's remains (Seperti seekor hiena yang menjijikan, dia berjongkok di atas jasad Hamzah)" ${ }^{96}$

Selayaknya hiena, R.A.A. Wiranatakoesoema V mengganti perumpamaan tersebut dengan harimau atau macan, hewan buas yang lebih dikenal dikalangan masyarakat Sunda: "Pětana Hindoen kana lajon Sajid Hamzah mah, hěnteu beda djeung maoeng. Leungeunna noe lambokot koe gětih, korowok dipake ngabebekkeun dadana lajon, atina dikodok toeloej digegelan bari amběk (Perlakuan Hindun terhadap jasad Sayid Hamzah, tidak ada bedanya dengan harimau. Tangannya berlumuran darah, dipakai untuk merusak dada jasad, hatinya dikeluarkan kemudian digigit berkali-kali dengan penuh amarah)" ${ }^{97}$ Hal yang menarik adalah perumpamaan ini memiliki arti yang sama dengan definisi nama pupuh yang digunakan, yakni harimau. Peristiwa yang terkandung dalam dangding ini pun diwarnai dengan kemarahan, konflik, serta permusuhan yang terjadi di medan perang, yang merupakan karakteristik pupuh Durma.

\section{Penutup}

Demikian uraian mengenai kontribusi R.A.A. Wiranatakoesoema V dalam menyumbangkan karya terjemah yang mewarnai literatur sejarah hidup Nabi saw. awal yang dicetak menggunakan aksara Latin dan Arab di Tatar Sunda. Pola penulisan prosa khas Barat yang mulai memengaruhi karya-karya

\footnotetext{
${ }^{95}$ Ma’mur Danasasmita, Sastra Sunda..., hlm. 26.

${ }^{96}$ E. Dinet dan Sliman Ben Ibrahim, The Life of Mohammad, hlm. 88.

${ }^{97}$ R.A.A. Wiranata Koesoema, Riwajat Kangdjeng..., hlm. 144.
} 
tulis Sunda kian membaur dan diterima oleh masyarakat Sunda. Fenomena ini mendorong Dalem Haji untuk memadukan corak penulisan tradisional Sunda dengan corak penulisan modern ala Barat. Keragaman karakteristik dangding karya R.A.A. Wiranatakoesoema $\mathrm{V}$ pun menghiasi setiap peristiwa dengan pendekatan emosional yang sesuai dengan tema peristiwanya. Selain itu, peran dangding pada masa itu begitu mendominasi masyarakat Sunda, sehingga melantunkan dangding menjadi sebuah hiburan sekaligus pendidikan. Penerjemah menempatkan dangding sebagai alat untuk mempermudah pembaca agar menghayati serta memahami kandungan isi maupun konteks peristiwa yang dibacanya. Selain itu, dangding yang lantunkan akan mudah dihafal dan dinyanyikan oleh kaum muda maupun tua, terutama anak-anak. Hal ini akan mendekatkan setiap gerak kehidupan masyarakat Pasundan dengan nilai-nilai kehidupan yang diwariskan Rasulullah saw., hingga pembaca bisa dengan mudah mengingat serta menikmati bacaan yang telah dibacanya. 
Kontribusi R.A.A. Wiranatakoesoema...... | Asep Achmad H, dkk

\section{Daftar Pustaka}

Arsip Orang Terkemuka di Jawa No. 2922. 2603. Lembar Pendaftaran Orang Indonesia Jang Terkemoeka Jang Ada Di Djawa. Bandoeng: Gunseikanbu Tjabang I.

Danasasmita, Ma'mur. 2011. Sastra Sunda Lama. Jilid II. Kabupaten Bandung: Penerbit Kelir.

Dinet, E. dan Ben Ibrahim, Sliman. 1918. The Life of Mohammad - The Prophet of Allah. Paris: The Paris Book Club.

Gunseikanbu. 2604. Orang Indonesia Jang Terkemoeka Di Djawa. cet. I. Jakarta: Gunseikanbu.

Hendrayana, Dian. 2010. Wiranatakusumah, Degung, dan Cianjuran. Bandung: Selisik Pikiran Rakyat, Senin (PON) 1 Maret 2010; 15 Rabiul Awal $1431 \mathrm{H}$; Mulud 1943.

Kodariah, Siti dan Gunardi, Gugun. 2015. Nilai Kearifan Lokal dalam Peribahasa Sunda: Kajian Semiotika. Bandung: Jurnal Patanjala Vol. 7 No. 1, Maret 2015.

Lings, Martin. 2014. Muhammad: Kisah Hidup Nabi Berdasarkan Sumber Klasik. Cet. XV. Jakarta: PT. Serambi Ilmu Semesta.

Loir, Henri Chambert. 2013. Naik Haji Di Masa Silam: Kisah-kisah Orang Indonesia Naik Haji 1482-1964. Jilid II. Jakarta: Kepustakaan Populer Gramedia.

Lubis, Nina Herlina. 1998. Kehidupan Kaum Menak Priangan 1800-1942. Bandung: Pusat Informasi Kebudayaan Sunda. dkk. 2011. Sejarah Provinsi Jawa Barat. Jilid II.

Bandung: Pemerintah Provinsi Jawa Barat.

Mangle, No. 1233, 25-31 Januari 1990.

Mikihiro, Moriyama. 2005. Semangat Baru: Kolonialisme, Budaya Cetak, dan Kesastraan Sunda Abad ke-19. Jakarta: Kepustakaan Populer Gramedia.

P., Suwardi Alamsyah dan Wiryono, Herry. 1995. Pengungkapan Nilai

Budaya Wawacan Amungsari-Lembusari. Bandung: Departemen Pendidikan dan Kebudayaan, Direktorat Jenderal Kebudayaan, Balai Kajian Sejarah dan Nilai Tradisional Jawa Barat. dkk, Analisis Struktur Sajarah Carita Lampahing

Para Wali Kabeh, (Bandung: Departemen Pendidikan dan Kebudayaan, Direktorat Jenderal Kebudayaan, Balai Kajian Sejarah dan Nilai Tradisional, 1999/2000), hlm. 10-11.

Prasasti Masdjid Kaoem Boeahbatoe.

Rahayu, Lina Meilinawati. 2015. Penerjemahan Karya Sastra Ke Dalam Bahasa Sunda Sebagai Strategi Pemberdayaan Bahasa Lokal. Bandung: Jurnal Tutur Universitas Padjadjaran Vol. 1 No. 1, Februari 2015. 
Rohmana, Jajang A. 2017. Sundanese Sira in Indonesia Archipelago: A Contribution of R.A.A. Wiranatakoesoema's Riwajat Kangdjeng Nabi Moehammad saw. Bandung: Jurnal Al-Albab Vol. 6, No. 1 Juni 2017. . t.t. Sastra Sufistik Sunda dan Peneguhan Identitas Islam Lokal: Kontribusi Dangding Haji Hasan Mustapa (1853-1930). Bandung: UIN Sunan Gunung Djati.

Rosidi, Ajip. 2004. Masa Depan Budaya Daerah: Kasus Bahasa dan Sejarah Sunda. Jakarta: PT Dunia Pustaka Jaya.

Setiawan, Hawe. Sebuah esai berjudul: Dangding Mistis Haji Hasan Mustapa. Sumber: salihara.org Kalam 28/2016, Diakses pada 31 Juli 2018.

Sudrayat, Yayat. 2003. Ulikan Semantik Sunda. Bandung: CV. Geger Sunten. Supardi, Moh. 2017. Dinamika Penerjemahan Sastra: South of The Slot. Jakarta: Buletin Al-Turas Mimbar Sejarah, Sastra, Budaya, dan Agama. Vol. XXIII No. 2. Juli 2017.

Thohir, Ajid. 2014. Sirah Nabawiyah: Nabi Muhammad saw Dalam Kajian Ilmu Sosial-Humaniora. Bandung: Penerbit Marja.

Tisnawerdaja, A. 1956. Widjining Sastra. Cet. II. Kuningan: Famtis.

Wiranata Koesoema, R.A.A. 1940. Het Leven van Muhammad - De Profeet van Allah. Bandung: Islam Studieclub MCMXL.

saw. Bandung: Islam Studieclub.

Yahya, Iip Dzulkifli. 2011. R.A.A.H.M. Wiranatakusumah V: Kedalaman yang belum terselami. Bandung: Yayasan Wiranatakusumah. . 2010. Wiranatakusumah, "Sosok Nu Masagi". Bandung: Selisik Pikiran Rakyat, Senin (PON) 1 Maret 2010; 15 Rabiul Awal $1431 \mathrm{H}$; Mulud 1943. . 2010. Sosok Pemimpin yang Dicintai Rakyatnya. Bandung: Selisik Pikiran Rakyat, Senin (PON) 1 Maret 2010; 15 Rabiul Awal $1431 \mathrm{H}$; Mulud 1943.

Yudibrata, Karna, dkk. 1990. Bagbagan Makena Basa Sunda. Bandung: Rahmat Cijulang.

Zaenal Arifin, E. 2016. Bahasa Sunda Dialek Priangan. Jurnal Pujangga Vol. 2 No. 1 Juni 2016. 
Kontribusi R.A.A. Wiranatakoesoema...... |Asep Achmad H, dkk 